\title{
Polyphenols and Human Health: The Role of Bioavailability
}

\author{
Chiara Di Lorenzo ${ }^{1, *(\mathbb{D}, \text { Francesca Colombo }}{ }^{1}$, Simone Biella ${ }^{1}$, Creina Stockley ${ }^{2}$ and Patrizia Restani $^{1, *(\mathbb{D})}$ \\ 1 Department of Pharmacological and Biomolecular Sciences, Università degli Studi di Milano, \\ 20133 Milan, Italy; francesca.colombo1@unimi.it (F.C.); simone.biella@unimi.it (S.B.) \\ 2 The Australian Wine Research Institute (AWRI), Glen Osmond 5064, Australia; creina.stockley@awri.com.au \\ * Correspondence: chiara.dilorenzo@unimi.it (C.D.L.); patrizia.restani@unimi.it (P.R.); \\ Tel.: +39-02-5031-8371 (P.R.)
}

check for updates

Citation: Di Lorenzo, C.; Colombo, F.; Biella, S.; Stockley, C.; Restani, P. Polyphenols and Human Health: The Role of Bioavailability. Nutrients 2021, 13, 273. https://doi.org/10.3390/ nu13010273

Received: 30 November 2020 Accepted: 14 January 2021 Published: 19 January 2021

Publisher's Note: MDPI stays neutral with regard to jurisdictional claims in published maps and institutional affiliations.

Copyright: (c) 2021 by the authors. Licensee MDPI, Basel, Switzerland. This article is an open access article distributed under the terms and conditions of the Creative Commons Attribution (CC BY) license (https:/ / creativecommons.org/licenses/by/ $4.0 /)$.

\begin{abstract}
Polyphenols are a group of phytochemicals with potential health-promoting effects. They are classified as flavonoid (flavonols, flavanols, flavones, flavanones, isoflavones, and anthocyanins) and non-flavonoid molecules (phenolic acids, hydroxycinnamic acids, lignans, stilbenes, and tannins). Although an increasing number of trials have shown a correlation among polyphenol consumption and a reduction in risk factors for chronic diseases, discrepancies in explaining their positive effects have been found in terms of the bioavailability. In fact, polyphenols show a low bioavailability due to several factors: interaction with the food matrix, the metabolic processes mediated by the liver (phase I and II metabolism), intestine and microbiota. On the other hand, the biological activities of phenol compounds may be mediated by their metabolites, which are produced in vivo, and recent studies have confirmed that these molecules may have antioxidant and anti-phlogistic properties. This review discusses the studies performed in vivo, which consider the polyphenol bioavailability and their different food sources. Factors influencing the biological effects of the main classes of polyphenols are also considered.
\end{abstract}

Keywords: polyphenols; bioavailability; beneficial effects; human studies

\section{Introduction}

It is known that an appropriate diet and lifestyle are essential for preserving wellbeing and preventing illnesses. Due to their abundance in foods derived from plants (e.g., vegetables, fruits, and beverages) and their potential antioxidant activity, polyphenols have been considerably studied in the past years as adjuvants in attenuating the risk factors for disabling diseases (mainly cardiovascular disease (CVD), diabetes, cancer, and cognitive disorders) [1]. Polyphenols are phenylpropanoids synthetized by plants as secondary metabolites, in adverse situations, such as in the presence of pathogens or under adverse climatic conditions. More than 8000 phenolic molecules have been identified, which must contain at least one aromatic nucleus and one or more -OH groups [2]. Polyphenols are commonly categorized as flavonoids, characterized by a C6-C3-C6 structure, and nonflavonoids. Flavonoids generally present in foods are anthocyanins, flavonols, flavan-3-ols, flavones, isoflavones, flavanones, and stilbenes (Figure 1).

Most flavonoids found in foods are conjugated with sugars, acids, or alcohols. Nonflavonoids include phenolic acids, in particular, hydroxybenzoic acids (i.e., vanillic and gallic acids), and cinnamic acids (i.e., ferulic and caffeic acids). All of these molecules have proven to have biological activities [3,4]; however, most of them have been shown using in vitro models and pure compounds, where the metabolism and matrix effect were not taken into account. This is due to the fact that in vitro approaches enable the specific mechanisms of action of each molecule/group of molecules to be identified, with relatively low costs. Unfortunately, in vitro studies do not take into account the metabolic transformations and physiological concentrations [5]. 


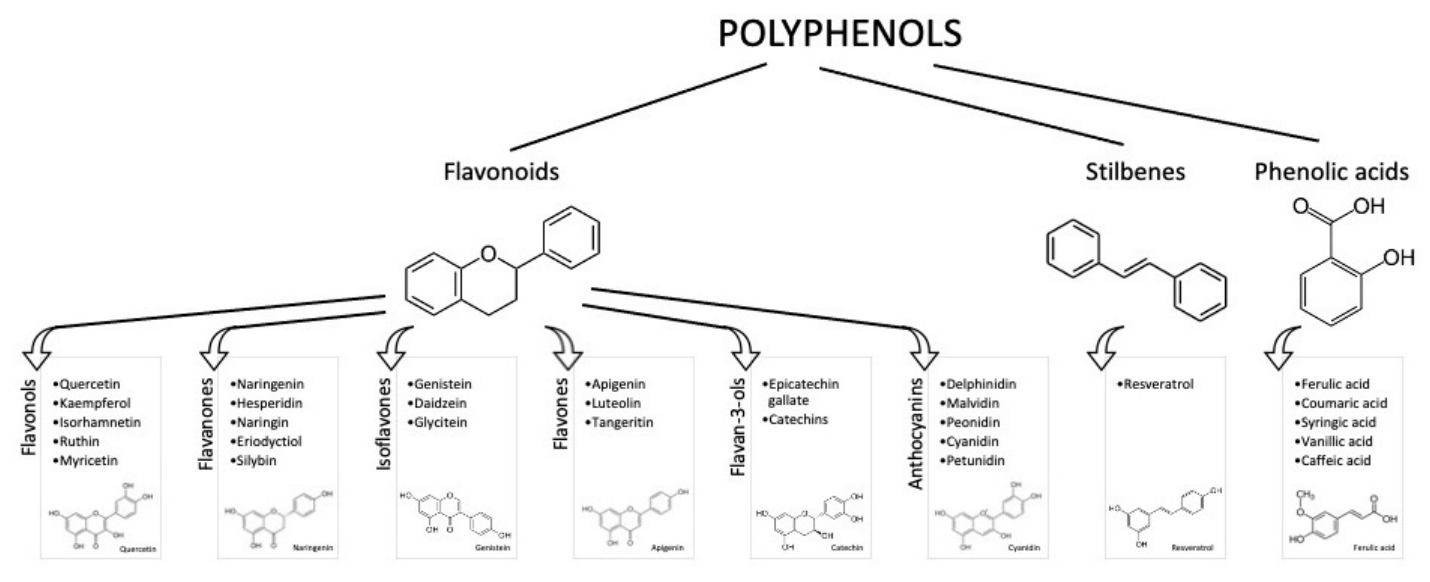

Figure 1. Polyphenol classes and chemical structures of some of their main compounds.

As regards in vivo studies, although several epidemiological and clinical studies have evaluated the polyphenol intake, several of them present several limitations, such as a low number of participants, no controls, the use of different methodologies to assess dietary habits, heterogeneous types of database to determine the consumption, etc. Despite the fact that other large and well-designed studies (for example, the PREDIMED study) have shown that the Mediterranean diet, characterized by foods rich in polyphenols, is associated with a reduction in cardiovascular risk and a better cognitive function in the elderly, strong evidence supporting its effects on human health is still not clear [6]. This is also due to the scarcity of knowledge regarding polyphenol bioavailability, together with the difficulty in determining which specific molecule is involved in the biological effect when different phenol compounds are present concomitantly. To date, only cocoa and extra virgin olive oil have thus received the approval of a health claim related to the content in phenol compounds.

Lastly, besides the polyphenol content in foods, in order to establish a correlation between the bioavailability and health effects, their mean intake in humans has to be considered. In a recent systematic literature revision, including more than 90 human studies, the polyphenol intake was estimated according to different dietary habits. Total polyphenol intake for the general population (inclusive of young people, adults, and the elderly) was estimated to be $0.9 \mathrm{~g}$ per day, where the main dietary founts were coffee, tea, wine (especially red wine), fruits, and vegetables. Total flavonoids and specific subclasses (flavonols, anthocyanidins, proanthocyanidins, flavan-3-ols, flavones, and flavanones) were associated with reduced CVD, diabetes mellitus (T2D), and mortality for all causes [7]. However, a correlation with the bioavailability of these compounds was not evaluated.

The goal of the present review was to assess the human bioavailability of the main classes of polyphenols, taking into account their food sources and the main factors affecting their in vivo accessibility.

\section{Materials and Methods}

The most important life-science databases of references and abstracts (PubMed, MEDLINE, Embase, and CAB-Abstract) were methodically analyzed (from database beginning to October 2020), using the following terms: "polyphenols", "anthocyanins", "flavanols", "flavonols", "flavans", "stilbenes", "flavanones" in combination with "bioavailability", "disease", "health" and refining the results for "human studies" AND "controlled trials".

A search by title and abstract led to the collection of 98 relevant publications on the association between polyphenols and bioavailability. By removing duplicates and non-relevant papers (papers investigating the effects of polyphenols without considering bioavailability data, studies performed on animals, or using in vitro models), in total, 37 publications were included in this review. 


\section{Results and Discussion}

\subsection{Anthocyanins}

Anthocyanins are pigments soluble in water contributing to the red, violet, and blue colors in flowers and fruits. At low $\mathrm{pH}$, the anthocyanin chemical structure presents a positive charge at the oxygen atom of the C-ring, called the flavylium ion, and appears as red pigments. Anthocyanins are classified on the basis of the number and position of $-\mathrm{OH}$ groups on the flavonoid molecule. To date, more than 600 anthocyanin compounds have been identified [2]. Of these, the glycosylated form of cyanidin, delphinidin, malvidin, peonidin, petunidin, and pelargonidin are the most abundant. The most common sugar in anthocyanidin glycosides is glucose; however, rhamnose, galactose, and rutinose may also be present. The sugar group can be acylated, generally at $\mathrm{C} 3$ position, by aromatic acids such as hydroxycinnamic acids (ferulic, caffeic, and coumaric).

Anthocyanins are among the polyphenol compounds with the highest concentration in foods, with an average concentration of $115 \pm 259 \mathrm{mg}^{100 \mathrm{~g}^{-1}}$ [8]. The richest sources of anthocyanins (as glycosides) are black elderberries (1316 mg $100 \mathrm{~g}^{-1}$ ), black chokeberry (878 mg $100 \mathrm{~g}^{-1}$ ), and black currant (595 mg $100 \mathrm{~g}^{-1}$ ). Apart from red fruits, important sources of anthocyanins are represented by red wine, colored beans, and vegetables such as red oranges, red lettuce, or red onions. Like other flavonoids, the mean daily intake of anthocyanins can vary among countries, depending on the nutritional habits and cultural differences. It has been calculated that the daily intake of anthocyanins is between $6.8 \mathrm{mg}$ per day in Brazil (where the most important dietary sources are citrus and tropical fruits) and Australia, and $133 \mathrm{mg}$ per day in Italy (the main dietary sources are seasonal fruits, citrus fruits, leafy vegetables, and wine) [9-11].

Anthocyanin bioavailability is extremely low: only about $1-2 \%$ maintain their original structure after ingestion [12]. Anthocyanins exist in different chemical structures depending on the $\mathrm{pH}$. In the stomach, at $\mathrm{pH} 1.5-3$, the main chemical forms are flavylium cations, while in the intestinal environment, the carbinol forms predominate, with lower absorption. In addition, other biotransformation steps occur during gastrointestinal digestion, such as phase II metabolism processes (glucuronidation, sulphation, and methylation), enzymatic and microbiota catabolism [12]. These lead to several chemical compounds, namely anthocyanin glucuronides, phenolic acids (ferulic acid, caffeic acid, vanillic acid, gallic acid, protocatechuic acid, syringic acid, and 4-hydroxybenzoic acid), and aldehydes (phloroglucinaldehyde and phloroglucinaldehyde) [12]. Nevertheless, there is a remarkable inter- and intra-variability in the bioavailability of anthocyanins, due to several factors, such as the food matrix or technological/processing conditions, enzymatic patterns, and microbiota composition. Only a few studies have evaluated a correlation among the results obtained and the bioavailability data. Table 1 summarizes the human trials where the health properties of anthocyanins are correlated with bioavailability studies. The literature data show that the anthocyanin daily doses used in the clinical trials ranged between 2.1 and $94.47 \mathrm{mg}$. These amounts were generally provided by food (blackcurrant and orange juice); and only the study by Xie et al. (2017) used a food supplement [13]. When anthocyanins were consumed in food, they did not affect the biomarkers investigated, mainly associated with the cardiovascular function, such as the oxidative status, inflammation and vascular reactivity. Only in the study by Xie et al., (2017) $500 \mathrm{mg} /$ day of Aronia extract (Aronia melanocarpa, also known as black chokeberry), containing $45.1 \mathrm{mg}$ anthocyanins, $35.7 \mathrm{mg}$ hydroxycinnamic acids, and $41.9 \mathrm{mg}$ proanthocyanidins, improved the total plasma cholesterol and LDL (Low-Density Lipoproteins) receptor in peripheral blood mononuclear cells [13]. This positive effect was due to the duration of the study (12 weeks vs acute consumption or a maximum of four weeks in the other studies) and by the synergistic effect of other phenol compounds present in the extract (hydrocynnamic acids and proanthocyanidins). These results are also supported by the literature data, where the chronic consumption, from six weeks to two months, of Aronia berry extracts (255-300 mg/day) decreased several biomarkers of cardiometabolic diseases, due to the high Aronia polyphenol content [14,15]. 
In addition, the studies were generally performed on healthy subjects, thus making it more difficult to measure evident effects on the health status.

Regarding the bioavailability data, the amounts of anthocyanins found in plasma or urine were generally low, which was correlated with the dose taken and the kind of food provided in the studies. Jin et al. (2011) hypothesized that blackcurrant juice did not ameliorate the vascular reactivity in healthy subjects, due to the low levels of anthocyanins in the juice (20\%) [16]. This observation has been supported by other authors, who reported that a consistent elevation of plasma anthocyanins and, as a consequence, significative health effects, can be observed only when anthocyanins are consumed at pharmacological levels $(500-1500 \mathrm{mg} /$ day) $[17,18]$. It is also noticeable that anthocyanin compounds are affected by high instability and susceptibility to degradation, particularly at the gastrointestinal level [19]. In addition, the short periods of supplementation or juice ingestion (maximum 12 weeks) were also found to influence the lack of a significant reduction in oxidative status and CVD biomarkers. In urine, the percentage of anthocyanins varied between $0.009 \pm 0.002$ and $0.79 \pm 0.90 \%$ of the dose taken, in line with the literature data $[20,21]$. Despite the great variability in anthocyanin food content, cyanidin and peonidin glucosides were generally considered the most available, since their metabolites were the only ones measurable in plasma or urine. In their clinical trial, Xie et al. (2017) speculated that the $8 \%$ reduction in fasting plasma total cholesterol after 12 weeks of supplementation with Aronia extract was also due to cyanidin methylated metabolite and 3(4-hydroxyphenyl)propionic acid derived from microbiota fermentation [13]. However, the mechanism by which these metabolites affect lipid metabolism needs to be further explored. Despite the general lack of positive effects on CVD biomarkers, several trials have described positive effects of anthocyanins when included in the daily diet. For example, Wedick et al. (2012) reported that the anthocyanin intake of about $22.3 \mathrm{mg}$ per day and an anthocyaninrich fruit consumption ( $\geq 5$ times per week) was correlated with a minor risk of developing type-2 diabetes [22]. Cassidy et al. (2016) reported a decreased risk of myocardial infarction in normotensive patients $>65$ years, when high levels of anthocyanins were consumed (>35 mg/day) [23]. Other studies reported positive effects of food supplements containing anthocyanins on ocular function, showing encouraging results in relation to glaucoma and in the reduction of retinal oxidative stress due to aging. However, in these studies, anthocyanin bioavailability was not considered. Manach et al. (2005) partially explained the discrepancies in the positive effects of anthocyanin despite their low anthocyanin bioavailability, by considering the following: (1) the possible presence of anthocyanin metabolites not measured in biological samples, such as microbiota metabolites; (2) the instability of anthocyanin metabolites (glucuronides and sulfates), which can extensively degrade in frozen urine, during storage [20]. 
Table 1. Anthocyanin's beneficial effects and bioavailability in human subjects.

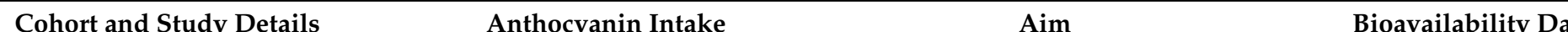

Cohort and Study Details Anthocyanin Intake Aim Bioavailability Data

- Treatment group $(n=25)$ :

49 healthy adult former smokers (25 M; $24 \mathrm{~F})$ (mean age $35 \pm 2.8$ years) Duration: 12 weeks

Randomized controlled trial

$500 \mathrm{mg}$ Aronia melanocarpa extract (9.02\% anthocyanins, $7.14 \%$ hydroxycinnamic acids and $8.38 \%$ proanthocyanidins).

- $\quad$ Placebo group $(n=24)$ :

$500 \mathrm{mg}$ rice powder with $0.2 \%$ beet juice concentrate.

\section{$250 \mathrm{~mL}$ of either a blackcurrant juice} drink ( $20 \%$ of anthocyanins) or the control drink. Sample collection after (9 M; 11 F) mean age $(44.55 \pm 13.34$ years $)$

Duration: acute consumption consumption

Randomized, double-blind,

placebo-controlled

- Blood: periodically up to $480 \mathrm{~min}$;

Modulation plasma lipids (change in LDL cholesterol was the primary outcome) blood pressure, biomarkers of inflammation and oxidative stress, lipid transport genes of peripheral blood mononuclear cells.

To measure vascular reactivity at $120 \mathrm{~min}$ after juice consumption.

- Urine: every $2 \mathrm{~h}$ and at $24 \mathrm{~h}$.

$480 \mathrm{~mL}$ cranberry juice ( $54 \%$ juice;

$835 \mathrm{mg}$ total polyphenols; $94.47 \mathrm{mg}$ anthocyanins).

Sample collection after consumption:

- $\quad$ Plasma and urine: after $4 \mathrm{~h}$.

Duration:

Pilot study

- $\quad$ Treatment group $(n=11)$

$750 \mathrm{~mL}$ per day $(3 \times 250 \mathrm{~mL})$ of

cranberry juice (total anthocyanins $=2.80$ $\pm 0.19 \mathrm{mg} \mathrm{L}^{-1}$; where $29.2 \%$ peonidin

20 healthy females (mean age: $27.8 \pm 7$ years) Randomized controlled trial Duration: 2 weeks
To evaluate plasma redox capacity. galactoside, $26.1 \%$ cyanidin arabinoside $21.7 \%$ cyanidin galactoside, $17.5 \%$ peonidin arabinoside, $4.1 \%$ peonidin glucoside, and $1.4 \%$ cyanidin glucoside).

- $\quad$ Placebo group $(n=9)$ :

natural mineral water with strawberry flavor

Overnight urinary anthocyanins were

Plasma antioxidant activity and biomarkers of oxidative stress (total phenol concentrations, reduced glutathione levels (GSH) and plasma free radical trapping capacity (FRAP)) Activity of blood's antioxidant enzymes (SOD, catalase and GSH-Px). Urinary excretion of MDA and 8-oxo-deoxyguanosine (as marker of DNA damage). significantly higher in the treatment group vs. placebo group $(0.332 \pm 0.136$ vs. $0.051 \pm 0.022 \mathrm{mg} \mathrm{mg}^{-1}$ creatinine)

Urinary peonidin-3-galactoside was $0.0062 \pm 0.0026 \mathrm{mg} \mathrm{mg}^{-1}$ creatinine in the treatment group vs. $0.0008 \pm 0.0005$ $\mathrm{mg} \mathrm{mg}^{-1}$ creatinine in placebo group $(p<0.05)$. The excretion of the other polyphenols was not significantly affected.

The urinary percentage anthocyanins excreted after $120 \mathrm{~min}$ was $0.021 \pm 0.003 \%$ and $0.009 \pm 0.002 \%$ of the dietary intake of delphinidin glycosides and cyanidin glycosides, respectively.

Plasma concentrations ranged between 0.56 and $4.64 \mathrm{nmol} \mathrm{L}^{-1}$. Total urinary anthocyanins were $0.79 \pm 0.90 \%$ of the amount taken. Cyanidin-glucoside and peonidin-glucoside were the most available $(0.007 \pm 0.004 \%$ and

$0.029 \pm 0.059 \%$ of the dose delivered).

After 12 weeks, Aronia consumption compared with the placebo group showed: $\downarrow 8 \%$ fasting plasma total cholesterol $(p=0.0140)$

$11 \%$ LDL cholesterol $(p=0.02)$

$\downarrow$ LDL receptor protein in peripheral blood mononuclear cells $(p=0.0036)$

No significant effects on vascular reactivity were found.

An increase in plasmatic vitamin $C$ was observed $(p=0.006)$.

Anthocyanin plasmatic concentrations were not able to reduce oxidative stress.
Neither anthocyanins nor catechins were detectable in plasma samples isolated from both groups, only vitamin $C$ increased significantly $(p<0.01)$ in the cranberry juice group Further, catechins were not detectable in the urine samples.
Hcy, TC, TG, HDL, and LDL were unchanged. The antioxidant potential of the plasma, GSH-Px, catalase and SOD activities, MDA and

8-oxo-deoxyguanosine levels were not significantly different in both groups. 
Table 1. Cont.

\begin{tabular}{|c|c|c|c|c|c|}
\hline Cohort and Study Details & Anthocyanin Intake & Aim & Bioavailability Data & Outcome & Reference \\
\hline $\begin{array}{l}18 \text { healthy subjects } \\
(10 \mathrm{M} ; 8 \mathrm{~F}) \\
\text { (25-47 years) } \\
\text { Duration: } 4 \text { weeks } \\
\text { Randomized crossover study }\end{array}$ & $\begin{array}{l}1 \mathrm{~L} \text { per day of either blood orange juice } \\
\text { (OJ) (from Moro, Tarocco, and } \\
\text { Sanguinello varieties) or blond OJ that } \\
\text { contains no anthocyanins (from Valencia, } \\
\text { navel, and Belladonna varieties). } \\
\text { Blood orange juice contained: } \\
53.09 \pm 5.31 \mathrm{mg} \mathrm{L}^{-1} \text { total anthocyanins, } \\
3.96 \pm 0.20 \mathrm{mg} \mathrm{L}^{-1} \\
\text { delphinidin-3-glucoside, } 25.79 \pm 1.17 \mathrm{mg} \\
\mathrm{L}^{-1} \text { cyandin-3-glucoside, } 17.88 \pm 0.95 \mathrm{mg} \\
\mathrm{L}^{-1} \text { cyanidin-3-(6-malonylglucoside). }\end{array}$ & $\begin{array}{l}\text { Potential effects on cell } \\
\text { markers of platelet and } \\
\text { leukocyte activation } \\
\text { (P-selectin, PAC-1, leukocyte } \\
\text { activation markers CD11b) } \\
\text { due to anthocyanins } \\
\text { absorption after daily } \\
\text { supplementation with blood } \\
\text { OJ for } 1 \text { month. }\end{array}$ & $\begin{array}{l}\text { Mean levels of anthocyanins } \\
\left(11.47 \pm 5.63 \text { nmol } \mathrm{L}^{-1}\right) \text { significantly } \\
\text { differed from baseline in } 24-\mathrm{h} \text { urinary } \\
\text { excretion. Anthocyanins levels } \\
\text { remained substantially unchanged } \\
\text { until the end of treatment }(p=0.1) .\end{array}$ & $\begin{array}{l}\text { The anthocyanin plasma } \\
\text { levels reached were } \\
\text { insufficient to significantly } \\
\text { modify cell markers of } \\
\text { platelet and leukocyte } \\
\text { activation and interaction. } \\
\text { Urinary excretions of } \\
\text { anthocyanins considered } \\
\text { showed a significant increase } \\
\text { after blood OJ consumption } \\
(p<0.05) \text {. }\end{array}$ & [26] \\
\hline
\end{tabular}

- $\quad$ Group A $(n=8)$

- Standardized diet without orange juice;

- Wash out period;

- Standardized diet with $600 \mathrm{~mL} /$ day of

blood orange juice.

- $\quad$ Group B $(n=8)$

16 healthy females

(20-27 years)

- Standardized diet with $600 \mathrm{~mL} /$ day of

blood orange juice;

- Wash-out period.

Duration: 3 weeks

Standardized diet without orange juice.

Each period was of 21 days.

$100 \mathrm{~mL}$ of orange juice contained:

$75.2 \mathrm{mg}$ vitamin C, $67 \mu \mathrm{g}$ of

$\beta$-cryptoxanthin, $20 \mu \mathrm{g}$ of lutein, $18 \mu \mathrm{g}$

of zeaxanthin, $17 \mu \mathrm{g}$ of lycopene, $10 \mu \mathrm{g}$

of $\beta$-carotene, and $8 \mu \mathrm{g}$ of $\alpha$-carotene,

$3.5 \mathrm{mg}$ cyanidin-3-glucoside, $1.2 \mathrm{mg}$

cyanidin-3-glucoside-6"-malonyl.
To evaluate the effect on

plasma antioxidant

concentrations and on

markers of lipid peroxidation

malondialdehyde (MDA) and

11-dehydro-tromboxane 2

(TXB2)
Cyanidin 3-glucoside mean plasma concentration was, after the washout period, about $0.6 \mathrm{nmol} \mathrm{L}^{-1}$ and increased from $0.56 \mathrm{nmol} \mathrm{L}^{-1}$ to $\sim 8 \mathrm{nmol} \mathrm{L}{ }^{-1}$ after 3 weeks of blood orange juice intake $(p<0.05)$. Both the aglycone and the

cyanidin-3-glucoside-6"'-malonyl were not detected in plasma.
Plasma antioxidant capacity did not increase after the 3 weeks of juice intake. The daily intake of orange juice did not affect the biomarker of lipid oxidation malondialdehyde (MDA) and 11-dehydro-TXB2

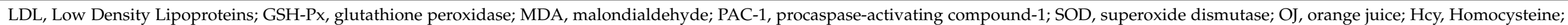

TG, triglycerides. 


\subsection{Flavanols}

Flavanol compounds are included in a wide of range of foods. The main sources of

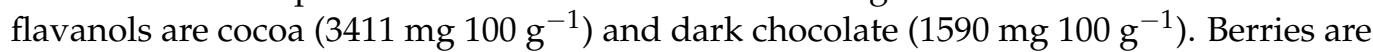

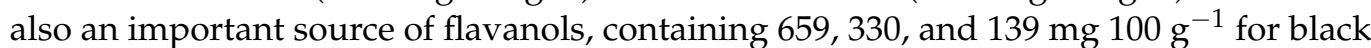

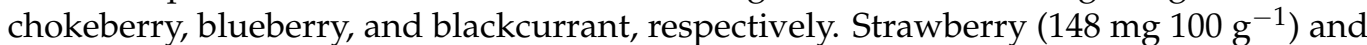
apple (111 mg $\left.100 \mathrm{~g}^{-1}\right)$, as well as hazelnut, pecan nut, pistachio, and almonds (181-496 mg $\left.100 \mathrm{~g}^{-1}\right)$, are other important sources. Black tea, green tea, and red wine contain high levels of flavanols, in particular, catechins and proanthocyanidin dimers, with estimated mean amounts of $18-50 \mathrm{mg}$ in the daily diet [20].

However, the content of some flavanols is often underestimated, since generally the methods used (e.g., HPLC) only evaluate monomers and proanthocyanidin dimers and trimers. The intake of flavanols in the European Union, according to the EFSA (European Food Safety Authority) Comprehensive European Food Consumption Database, and the average intake of flavan-3-ol monomers, theaflavins, and proanthocyanidins ranges from $181 \mathrm{mg}$ per day (Czech Republic) to $793 \mathrm{mg}$ per day (Ireland) [28].

The highest intakes of flavan-3-ols (monomers) and theaflavins were detected in Ireland (191 and $505 \mathrm{mg}$ per day, respectively) and the lowest in Spain (24 and $9 \mathrm{mg}$ per day, respectively). On the other hand, the highest daily intake of proanthocyanidins (PA) was found in Spain (175 mg per day) and lowest in The Netherlands (96 mg per day). The most important sources were tea $(62 \%)$, pome fruits (such as apples and pears) $(11 \%)$, berries $(3 \%)$, and cocoa derivatives ( $3 \%)$. Tea was the principal contributor to monomer intake $(75 \%)$, followed by pome fruits $(6 \%)$. In addition, pome fruits were the most important source of proanthocyanidins $(28 \%)$. Table 2 reports the clinical trials where the flavanol intakes and their bioavailability were correlated with beneficial effects. Flavanol intake ranged between 28.3 to $907.5 \mathrm{mg} /$ day. These amounts were chosen on the basis of the mean dietary intake of flavonosl among the population included in the studies, and thei consumption with food (enriched chocolate or coffee). Participants in the studies were generally healthy or had stage 1 hypertension without concomitant risk factors.

Dower et al. (2016) compared the chocolate consumption (containing $150 \mathrm{mg}$ epicatechin, EC) with pure epicatechin supplementation (100 mg) [29]. The length of treatment varied between acute consumption to 18 weeks. The principal outcomes investigated were associated with cardiovascular function (e.g., blood pressure, flow-mediated dilation, and platelet function) and antioxidant activity (e.g., LDL oxidation or plasma 8-isoprostane). A significant improvement in cardiovascular biomarkers was also generally observed for the consumption of low levels of flavanols ( $28.3 \mathrm{mg}$ /day). A significant improvement in cardiovascular biomarkers was also generally observed for the consumption of low levels of flavanols ( $28.3 \mathrm{mg} /$ day), despite the EFSA highlighting of a cause-effect correlation between cocoa consumption and endothelium vasodilation for a daily intake of $200 \mathrm{mg}$ [30]. In contrast, only a few studies have measured notable effects on oxidative stress, suggesting that other mechanisms can be involved in the improvement of cardiovascular function [31,32].

According to Taubert et al. (2007), the positive results were generally associated with the monomers epicatechin/catechin and the dimers procyanidin B2/procyanidin $\mathrm{B} 2$ gallate, which were the only monomers dosed in plasma, at a concentration ranging between $0.14( \pm 0.06) \mathrm{ng} / \mathrm{mL}$ of procyanidin B2 gallate and $3.63( \pm 1.02) \mathrm{ng} / \mathrm{mL}$ (from 1 to $6 \mathrm{~h}$ after consumption) [32]. These amounts reduced blood pressure by $1.9( \pm 1) \mathrm{mmHg}$ in patients with stage 1 hypertension probably due to the "chronic" increase in endothelium NO production. Similar effects were observed in other studies where higher levels of flavan-3-ols were used, due to the shorter period of intake. Interestingly, in the clinical trial by Dower et al. (2016), the positive effect of epicatechin (EC) on flow-mediated dilatation (FMD) from dark chocolate was not observed for pure epicatechin administered in association with white chocolate, suggesting a significant impact of the food matrix and sugar content on epicatechin bioavailability [29]. 
Urinary flavan-3-ols were measured only by Ostertag et al. (2013), who described a maximum catechin excretion of $13.4 \mathrm{mmol} / \mathrm{mol}$ creatinine 2-6 h after dark chocolate intake (containing $907.5 \mathrm{mg}$ total catechins) [33]. As regards platelet function, flavan-3-ols affected platelet aggregation 120 min after intake, when a peak plasma concentration was obtained. However, bleeding time was affected only after $360 \mathrm{~min}$, when the colonic metabolites kicked in Reference [33]. Interestingly, a gender-specific modulation of platelet aggregation reduction was also observed, probably due the formation of larger platelet aggregates after adenosine diphosphate (ADP) stimulation in women. It should also be noted that flavan-3-ol bioavailability varies markedly among the different subclasses. Manach et al. (2005) reported that galloylated catechins are poorly absorbed, explaining the higher bioavailability and the activity of epicatechin described in the clinical trials [20]. In addition, epicatechin glucuronide and sulfate metabolites, together with valerolactone microbial derivatives-not measured in the clinical trials included in this review-account for $6-39 \%$ of the ingested epicatechin, thus prolonging its biological effects [34].

As regards procyanidins, these compounds have a reduced bioavailability, which is about 100-fold lower than monomers. The biological effects are generally due to the monomers formed after gastric degradation, which can be rapidly absorbed in the gut. In addition, the gut microbiota is responsible for the metabolite formation (mhydroxyphenylpropionic acid, m-hydroxyphenylacetic acid, phenylpropionic acid, phenylacetic acid, hydroxyphenylvaleric acid, and benzoic acid among others), which could also be responsible for various biological effects [20]. 
Table 2. Flavanols' beneficial effects and bioavailability in human subjects.

\begin{tabular}{|c|c|c|c|c|c|}
\hline Cohort and Study Details & Flavanol Intake & Aim & Bioavailability Data & Outcome & Reference \\
\hline $\begin{array}{l}20 \text { healthy men } \\
\text { (40-80 years) } \\
\text { Duration: acute } \\
\text { consumption } \\
\text { randomized, placebo } \\
\text { controlled, crossover study }\end{array}$ & $\begin{array}{l}\text { Subjects consumed the following: } \\
\text { Dark chocolate }(\mathrm{DC})(70 \mathrm{~g} \text {, } \\
\text { containing } 0.15 \mathrm{~g} \text { EC) } \\
\text { associated with } 2 \text { capsules } \\
\text { of placebo; } \\
\text { Pure EC }(0.050 \mathrm{~g} \text {, purity } \\
96.2 \%)(\text { total EC }=0.100 \mathrm{~g}) \\
\text { associated with white } \\
\text { chocolate (WC) }(75 \mathrm{~g}) ; \\
2 \text { capsules of placebo with } \\
75 \mathrm{~g} \text { of WC (without EC). }\end{array}$ & $\begin{array}{l}\text { To study the effect of } \\
\text { epicatechin from different } \\
\text { matrices (cocoa and } \\
\text { supplement) on vascular } \\
\text { function (FMD and AIx). }\end{array}$ & $\begin{array}{l}\text { DC intake determined an Area Under the } \\
\text { Curve of } 16.2 \mu \mathrm{M} \text { (per } 0.100 \mathrm{~g} \text { of EC) that } \\
\text { was not significantly different from Area } \\
\text { Under the Curve calculated for pure EC } \\
(p=0.14) .\end{array}$ & $\begin{array}{l}\text { Pure EC didn't ameliorate Flow } \\
\text { Mediated Dilatation }(+0.75 \% ; \\
p=0.10) \text { or Augmentation Index } \\
(2.2 \% ; p=0.23) \text { respect to placebo. } \\
\text { DC significantly ameliorated } \\
\text { Flow Mediated Dilatation } \\
(+0.96 \% ; p=0.04) \text { and } \\
\text { Augmentation Index }(4.6 \% ; \\
p=0.02) . \text { Amelioration of FMD } \\
(+0.21 \% ; p=0.65) \text { or Aix }(-2.4 \% ; \\
p=0.20) \text { was not different after } \\
\text { pure EC and DC intake. EC } \\
\text { bioavailability was not different } \\
\text { after pure EC and DC }(p=0.14) .\end{array}$ & [29] \\
\hline $\begin{array}{l}21 \text { healthy subjects } \\
\text { (11 M; } 11 \mathrm{~F}) \text { (mean age: } \\
32.2 \pm 3.1 \text { years) } \\
\text { Duration: } 2 \text { weeks } \\
\text { Randomized, double-blind, } \\
\text { controlled with } \\
\text { placebo study }\end{array}$ & $\begin{array}{l}\text { The following treatments were } \\
\text { assigned: } \\
\text { - } \quad \text { High-flavonoid chocolate } \\
\text { intake }(0.213 \mathrm{~g} \text { PC, } 0.046 \mathrm{~g} \mathrm{EC}) \\
\text { per day; } \\
\text { - Low-flavonoid DC }(46 \mathrm{~g}) \\
\text { per day. }\end{array}$ & $\begin{array}{l}\text { To evaluate the impact of DC } \\
\text { enriched with flavonoids on } \\
\text { FMD, blood pressure, } \\
\text { markers of oxidative stress } \\
\text { (LDL-ox, total antioxidant } \\
\text { power, 8-isoprostane levels } \\
\text { and plasmatic lipid } \\
\text { concentrations). }\end{array}$ & $\begin{array}{l}\text { Plasmatic EC levels were significantly } \\
\text { higher at two weeks after high-flavonoid } \\
\text { DC consumption }\left(204.4 \pm 18.5 \mathrm{nmol} \mathrm{L}^{-1}\right. \\
p<\text { or }=0.001) \text { than after low-flavonoid DC } \\
\text { intake }\left(17.5 \pm 9 \mathrm{nmol} \mathrm{L}^{-1}, p=0.99\right)\end{array}$ & $\begin{array}{l}\text { The intake of chocolate } \\
\text { containing high levels of } \\
\text { flavonoids ameliorated FMD } \\
\text { (average change }=1.3 \pm 0.7 \% \text { ) } \\
\text { respect to the groups consuming } \\
\text { chocolate with low levels of } \\
\text { flavonoids (mean change }=-0.96 \\
\pm 0.5 \%)(p=0.024) . \text { LDL-ox, } \\
\text { antioxidant power, } \\
\text { 8-isoprostanes, blood pressure, } \\
\text { lipid biomarkers were not } \\
\text { significantly in the two groups. }\end{array}$ & [31] \\
\hline
\end{tabular}


Table 2. Cont.

Only catechin, epicatechin and the dimers

procyanidin B2 and procyanidin B2 gallate

were measured in plasma and didn't

change after 18 weeks. Pharmacokinetic

data were: Epicatechin: AUC from

$761( \pm 210) \mathrm{ng} \mathrm{mL}^{-1} \times \min$ on day 1 to

$774( \pm 253) \mathrm{ng} \mathrm{mL} L^{-1} \times \min (p=0.82)$ at

18 weeks; Cmax from $3.63( \pm 1.02) \mathrm{ng} / \mathrm{mL}$

on day 1 to $3.58( \pm 0.92) \mathrm{ng} \mathrm{mL}^{-1}(p=0.78)$

at 18 weeks; Tmax from $77( \pm 4)$ min on

day 1 to $81( \pm 6) \mathrm{min}$ at 18 weeks $(p=0.70)$

Treated subjects $(n=22): 6.3 \mathrm{~g}$ dark chocolate per day providing $30 \mathrm{mg}$ of polyphenols per day $(1.4 \mathrm{mg}$

gallic acid, $1.7 \mathrm{mg}$ catechin, $5.1 \mathrm{mg}$ epicatechin, $0.3 \mathrm{mg}$

epicatechin-gallate, $6.8 \mathrm{mg}$

procyanidin dimer, 1.8 procyanidin

dimer-gallate, $5.3 \mathrm{mg}$ procyanidin

trimer, $1.0 \mathrm{mg}$ procyanidin

trimer-gallate, $3.7 \mathrm{mg}$ procyanidin

tetramer, $2.6 \mathrm{mg}$ procyanidin

pentamer, $<0.05 \mathrm{mg}$ flavonols,

$3.1 \mathrm{mg}$ caffeine, $26.4 \mathrm{mg}$ theobromine)

Control group $(n=22)$

polyphenol-free white chocolate.
To evaluate the change in blood pressure. Secondary objectives were the assessment of nitric oxide and oxidative stress plasmatic biomarkers (S-nitrosoglutathione and 8-isoprostane, respectively)

$\mathrm{T} 1 / 2$ from $54( \pm 3) \mathrm{min}$ on day 1 to $56( \pm 5)$ $\min (p=0.79)$ at 18 weeks.

Catechin: AUC from $234( \pm 61)$ (day 1) to $228( \pm 56) \mathrm{ng} \mathrm{mL}^{-1} \times \min (p=0.77) ; \mathrm{Cmax}$ from $1.12( \pm 0.31) \mathrm{ng} \mathrm{mL}^{-1}$ on day 1 to 1.01 $( \pm 0.26) \mathrm{ng} \mathrm{mL}^{-1}(p=0.58)$ at 18 weeks;

Tmax from $78( \pm 9)$ min on day 1 to $82( \pm 6)$ $\min$ at 18 weeks $(p=0.69)$ : T1 2 from 54

$( \pm 6)$ min on day 1 to $58( \pm 7) \min (p=0.68)$ at 18 weeks. Procyanidin B2: AUC from 99 $( \pm 30) \mathrm{ng} \mathrm{mL}^{-1} \times \min$ on day 1 to 102 $( \pm 32) \mathrm{ng} \mathrm{mL}^{-1} \times \min (p=0.90) ; \mathrm{Cmax}$ from $0.45( \pm 0.15) \mathrm{ng} \mathrm{mL}^{-1}$ on day 1 to $0.43( \pm 0.14) \mathrm{ng} \mathrm{mL}^{-1}(p=0.94)$ at 18 weeks; Tmax from $81( \pm 8) \mathrm{min}$ on day 1 to $86( \pm 9) \mathrm{min}$ at 18 weeks $(p=0.62) ; \mathrm{T} 1 / 2$ from $56( \pm 6) \mathrm{min}$ on day 1 to $57( \pm 5) \mathrm{min}$ $(p=0.91)$ at 18 weeks; procyanidin B2 gallate: AUC from $33( \pm 14) \mathrm{ng} \mathrm{mL}^{-1} \times$ min on day 1 to $33( \pm 13) \mathrm{ng} \mathrm{mL}^{-1} \times \min$ $(p=0.91)$; Cmax from $0.14( \pm 0.06) \mathrm{ng}$ $\mathrm{mL}^{-1}$ - day 1 to $0.14( \pm 0.06) \mathrm{ng} \mathrm{mL}^{-1}$ $(p=0.98)$ at 18 weeks; Tmax from $89( \pm 10)$ min on day 1 to $85( \pm 8)$ min at 18 weeks $(p=0.72) ; \mathrm{T} 1 / 2$ from $62( \pm 7) \mathrm{min}$ on day 1 to $59( \pm 6) \min (p=0.76)$ at 18 weeks.
At the end of the study, the treatment with dark chocolate educed mean systolic blood pressure by $2.9( \pm 1.6) \mathrm{mm} \mathrm{Hg}$ $(p<0.001)$ and diastolic blood pressure by $1.9( \pm 1) \mathrm{mm} \mathrm{Hg}$ $(p<0.001)$ but 8-isoprostane levels didn't change.

Hypertension prevalence was reduced from $86 \%$ to $68 \%$.

S-nitrosoglutathione levels (increased by $0.23 \mathrm{nmol} \mathrm{L}^{-1}$ $( \pm 0.12)(p<0.001)$ 
Table 2. Cont

\begin{tabular}{|c|c|c|c|}
\hline Cohort and Study Details & Flavanol Intake & Aim & Bioavailability Data \\
\hline $\begin{array}{l}42 \text { healthy subjects }(26 \mathrm{M} \text {; } \\
16 \mathrm{~F} \text { ) } \\
\text { (mean age } 41 \pm 2.0 \text { years) } \\
\text { Duration: acute } \\
\text { consumption } \\
\text { Observer-blinded } \\
\text { randomized-controlled } \\
\text { crossover acute } \\
\text { intervention trial }\end{array}$ & $\begin{array}{l}\text { Subjects received } 60 \mathrm{~g} \text { of dark } \\
\text { chocolate enriched with } \\
\text { flavan-3-ols (with } 400 \mathrm{~mL} \text { water), } \\
60 \mathrm{~g} \text { of a "standard" dark chocolate } \\
\text { or } 60 \mathrm{~g} \text { of white chocolate (14 days } \\
\text { wash out period was used between } \\
\text { treatments). Sixty grams of } \\
\text { chocolate enriched with } \\
\text { flavan-3-ols contained: } 0.257 \\
\text { ( } \pm 1.06) \text { g epicatechin, } 53.6 \text { ( } \pm 0.27) \\
\text { mg catechin, } 0.198( \pm 1.22) \mathrm{g} \text { dimer } \\
\text { B2, } 0.168( \pm 1.42) \text { g trimers, } \\
0.105 \pm(12.75) \text { g tetramers, } \\
0.125 \pm(6.04) \text { g pentamers (total } \\
\text { flavonoids = 907.4 } \pm 22.75 \text { mg). } \\
\text { Sixty grams of "standard" dark } \\
\text { chocolate contained: } 84.1 \text { ( } \pm 0.67) \\
\text { mg epicatechin, } 25.8( \pm 1.02) \text { mg } \\
\text { catechin, } 74.4 \text { ( } \pm 0.76) \text { mg dimer } B 2, \\
47 \text { ( } \pm 2.23) \text { mg trimers, } 32.1 \text { ( } \pm 4.4) \\
\text { mg tetramers, } 0.119( \pm 39.5) \mathrm{g} \\
\text { pentamers (total flavonoids: } 382.3 \\
\pm 45.2 \text { mg). White chocolate }=\mathrm{ND} \text {. }\end{array}$ & $\begin{array}{l}\text { To evaluate if } \\
\text { flavan-3-ol-enriched dark } \\
\text { chocolate could influence } \\
\text { markers of platelet status } \\
\text { (adenosine } \\
\text { diphosphate-induced platelet } \\
\text { aggregation, expression of } \\
\text { P-selectin, thrombin } \\
\text { receptor-activating } \\
\text { peptide-induced platelet } \\
\text { aggregation and thrombin } \\
\text { receptor-activating } \\
\text { peptide-induced fibrinogen } \\
\text { binding, } \\
\text { collagen/epinephrine- } \\
\text { induced bleeding } \\
\text { time). }\end{array}$ & $\begin{array}{l}\text { Plasmatic levels of total C/EC significantly } \\
\text { increased } 120 \text { min after flavan-3-oil } \\
\text { enriched or "standard "dark chocolate in } \\
\text { comparison with white chocolate } \\
(p<0.001)\left(\text { Cmax }=1.20 \mu \mathrm{mol} \mathrm{L}^{-1} 120 \mathrm{~min}\right. \\
\text { after consumption of dark chocolate } \\
\text { enriched with flavan3-ols) and decreased } \\
\text { after } 6 \mathrm{~h} \text {. } \\
\text { Urinary levels of total catechins increased } \\
120 \text { and } 360 \text { min after consumption of } \\
\text { enriched dark or "standard" dark } \\
\text { chocolate in comparison with white } \\
\text { chocolate }(p<0.001) \text {, reaching a peak } \\
\text { concentration of } 13.4 \text { mmol mol } 1 \\
\text { creatinine. Comparable results were } \\
\text { observed for procyanidin dimer B } 2 \\
(p<0.001) \text {, reaching a peak concentration } \\
\text { at } 57 \mu \text { mol mol }{ }^{-1} \text { creatinine at } 360 \text { min. } \\
\text { The peak of flavan-3-ol concentrations was } \\
\text { higher in biological fluids of women } \\
(p=0.047) \text {. }\end{array}$ \\
\hline
\end{tabular}

18 healthy male subjects

(mean age: $36 \pm 10$ years)

Duration: acute

consumption

Observational study
Subjects consumed $50 \mathrm{~g}$ of $90 \%$ cocoa chocolate (containing $7.5 \mathrm{~g}$ total polyphenols expressed as GA equivalents) within $5 \mathrm{~min}$
To investigate the impact of dark chocolate on platelet status and the correlation with flavanols metabolites.
After $4 \mathrm{~h}$ from the ingestion, epicatechin metabolites concentration in plasma significantly increased (epicatechin glucuronide, sulfate

methyl-epicatechin-sulfate) $(p<0.05)$.
Enriched dark and white chocolate ameliorated different biomarkers of platelet status (adenosine diphosphate-induced platelet aggregation, $\mathrm{P}$-selectin expression, thrombin receptor-activating peptide-induced platelet aggregation and thrombin receptor-activating peptide-induced fibrinogen binding) following a gender-specific fashion.

An inhibitory effect of cocoa was observed on platelet aggregation and adhesion caused by

$\mathrm{ADP} /$ collagen $4 \mathrm{~h}$ after cocoa intake $(98.5 \pm 13.0$ respect to $114.5 \pm 22 \mathrm{~s}, p<0.001)$ was noticed, while the closure time of

collagen/epinephrine didn't change (128.5 $\pm 27.0 \mathrm{vs}$ $122.5 \pm 34$. $s, p=0.33)$, probably

\section{associated with EC metabolites.}

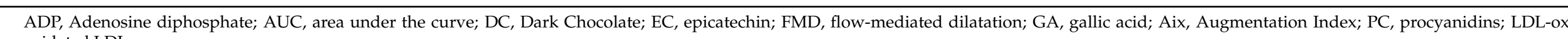




\subsection{Flavonols}

Fruits, vegetables, and some beverages, like tea and red wine, are the main source of flavonols, for which the intake is estimated between 18 (USA) and $58 \mathrm{mg}$ (Japan) per day [28]. However, these intake levels generally refer only to the three main flavonols, namely quercetin, myricetin, and kaempferol. In fruits and vegetables, the highest quercetin content is found in cranberry $(149 \mathrm{mg} / 100 \mathrm{~g})$ and onions $\left(65 \mathrm{mg} 100 \mathrm{~g}^{-1}\right)$, while in green tea and red wine, the mean contents are 2.5 and $1.6 \mathrm{mg} / 100 \mathrm{~mL}$, respectively [36]. Eleven studies have explored the different health effects of flavonol intake, mainly on the reduction in CVD risk factors (homocysteine and LDL-oxidation levels, homocysteine, plasmatic High Density Lipoproteins (HDL) and LDL cholesterol, blood pressure, NO production, and platelet aggregation), inflammatory biomarkers (C-reactive protein and endothelin-1 expression), and antioxidant activity (e.g., excretion of urinary F2-isoprostanes and plasma malondialdehyde (MDA)) (Table 3). One study also investigated the effect of an enzymatically modified quercetin on cognitive function [37]. These effects have generally been measured in healthy subjects, apart from three studies involving subjects at cardiovascular risk [37-39].

In most studies, flavonols were administered by extracts, given alone or mixed with food; only in three studies they were provided using food preparations (onion soup or cake) [40-42]. Flavonol intake ranged between 16.7 to $400 \mathrm{mg} /$ day and included mainly quercetin and its derivatives, isorhamnetin and kaempferol. The data in Table 3 show that cardiovascular parameters, as well as oxidative stress biomarkers, were generally not affected by flavonols. Suomela et al. (2006) and Larmo et al. (2009) used a sea buckthorn extract (Hippophae rhamnoides L.) as the source of flavonols (78 and $16.7 \mathrm{mg}$ per day, respectively), administered with meals $[38,43]$. Both flavonol intakes failed to reduce oxidative stress, total and LDL cholesterol, or C reactive protein (CRP) concentration. Sea buckthorn was administered because of its traditional use in Eastern countries and the encouraging results from clinical and epidemiological studies reporting a reduction in cardiovascular risk factors [44]. The authors explained the different outcomes of their studies, using a moderate berry dose, similar to the average consumption in the daily diet and to the dosage (3-9 g) prescribed by the Chinese Pharmacopoeia for ameliorating hematic circulation [45]. These amounts were lower than those used in other trials (600 mg sea buckthorn flavonols), where positive results were reported [46]. 
Table 3. Flavonols' beneficial effects and bioavailability in human subjects.

\begin{tabular}{|c|c|c|c|c|c|}
\hline Cohort and Study Details & Flavonol Intake & Aim & Bioavailability Data & Outcome & Reference \\
\hline $\begin{array}{l}25 \text { participants } \\
(12 \mathrm{M} ; 13 \mathrm{~F}) \\
\text { (mean age: } 64.1 \pm 6.3 \text { years) with } \\
\text { at least one CVD risk factor (sBP } \\
\text { 120-160 mmHg, FPG 5.6-6.5 } \\
\mathrm{mM} \text {, total cholesterol } 5-8 \mathrm{mM} \text { or } \\
\text { a waist circumference }>94 \mathrm{~cm} \text { for } \\
\text { men or }>80 \mathrm{~cm} \text { for women) } \\
\text { Duration: acute consumption } \\
\text { Randomized, controlled } \\
\text { crossover trial }\end{array}$ & $\begin{array}{l}\text { Treatment group: } \\
\text { - } 4.89 \mathrm{mg} / \mathrm{kg} \text { bw /day of EMIQ } \\
\text { (Enzymatically Modified IsoQuercitrin), } \\
\text { - half teaspoon of maltodextrin, } \\
\text { - one and half tablespoons of Cottee's } \\
\text { Raspberry flavored cordial. } \\
\text { Placebo group: } \\
\text { - half teaspoon of maltodextrin, } \\
\text { - one and half tablespoons of Cottee's } \\
\text { Raspberry flavored cordial, } \\
\text { The treatments were given in } 250 \mathrm{~mL} \text { of water. }\end{array}$ & $\begin{array}{l}\text { To evaluate if FMD, BP, and } \\
\text { cognitive function improve } \\
\text { whether an acute intake of } \\
\text { EMIQ }^{\circledR} \text { was administered. }\end{array}$ & $\begin{array}{l}\text { After } 3 \mathrm{~h} \text { from the consumption of } \\
\text { EMIQ }^{\circledR}, \text { quercetin metabolites } \\
\text { concentration was significantly higher } \\
\text { in plasma respect placebo group } \\
\text { (quercetin aglycone } 144.9 \pm 12.3 \mathrm{nM} \text { vs. } \\
12.6 \pm 12.3 \mathrm{nM} \text {; and isorhamnetin } \\
245.5 \pm 16.5 \mathrm{nM} \text { vs. } 41.7 \pm 16.5 \mathrm{nM}) \\
(p<0.001) .\end{array}$ & $\begin{array}{l}\text { EMIQ }^{\circledR} \text { significantly affected } \\
\text { FMD compared with the } \\
\text { placebo }(p=0.025) \text {. }\end{array}$ & [37] \\
\hline $\begin{array}{l}14 \text { healthy males } \\
(46.6 \pm 5.6 \text { years }) \text { with a } \\
\text { slightly elevated total } \\
\text { cholesterol level } \\
\text { ( } 5.3-7.2 \mathrm{mmol} / \mathrm{L}) \\
\text { Duration: } 4 \text { weeks } \\
\text { Double-blind, } \\
\text { placebo-controlled, crossover } \\
\text { study }\end{array}$ & $\begin{array}{l}\text { - Group 1: } \\
\text { daily consumption of } 185 \mathrm{~g} \text { of an } \\
\text { oatmeal porridge supplemented with a } \\
\text { flavonols extract of sea buckthorn } \\
\text { (Hippopae rhamnoides L.) } \\
\text { - Group 2: } \\
\text { consumption of control porridge } \\
\text { without flavonols. } \\
0.4 \text { g of extract, added to the porridge, } \\
\text { contained: } 78 \text { mg of total flavonol } \\
\text { aglycones, of which } 70 \% \text { isorhamnetin, } \\
26 \% \text { quercetin, and } 4 \% \text { kaempferol. }\end{array}$ & $\begin{array}{l}\text { To evaluate the effects on } \\
\text { CRP, conjugated dienes and } \\
\text { oxidized LDL, homocysteine, } \\
\text { and paraoxonase activity } \\
\text { (potential risk factors of CVD) } \\
\text { of a flavonols extract of sea } \\
\text { buckthorn. }\end{array}$ & $\begin{array}{l}\text { Flavonols were mainly present as } \\
\text { glucuronide and sulfate metabolites in } \\
\text { plasma fluid. } \\
\text { When was intake porridge added with } \\
\text { flavonols extract, AUC was } \\
\text { significantly higher for kaempferol and } \\
\text { isorhamnetin }(p<0.05) \text {. }\end{array}$ & $\begin{array}{l}\text { The flavonols ingested did } \\
\text { not significantly affect the } \\
\text { following: } \\
\text { - Oxidized LDL; } \\
\text { - CRP; } \\
\text { - Homocysteine levels; } \\
\text { - Plasma antioxidant potential; } \\
\text { - Paraoxonase activity. }\end{array}$ & [38] \\
\hline $\begin{array}{l}9 \text { overweight/obese men } \\
(n=4) \text { and post-menopausal } \\
\text { women }(n=5) \\
\text { (mean age }=55.9 \pm 2.1 \text { years) } \\
\text { Duration: acute consumption } \\
\text { Randomized, crossover study }\end{array}$ & $\begin{array}{l}\text { Subjects ingested quercetin aglycone } \\
(1095 \mathrm{mg}) \text { with } 3 \text { types of standardized } \\
\text { breakfast: } \\
\text { - Fat-free }(<0.5 \mathrm{~g}) \text {; } \\
\text { - Low-fat }(4.0 \mathrm{~g}) ; \\
\text { - High-fat }(15.4 \mathrm{~g}) \text {. }\end{array}$ & $\begin{array}{l}\text { To verify whether dietary fat } \\
\text { improve quercetin and its } \\
\text { metabolites bioavailability in } \\
\text { adults with high CVD risk. }\end{array}$ & $\begin{array}{l}\text { During the high-fat breakfast, } \\
\text { compared to the fat-free trial: } \\
\text { - Plasma quercetin: } \\
\uparrow 45 \% \text { Cmax; } \\
\uparrow 32 \% \text { AUC }(0-24 \mathrm{~h}) \text {; } \\
\text { - plasma isorhamnetin: } \\
\uparrow 40 \% \text { Cmax; } \\
\uparrow 19 \% \text { AUC }(0-24 \mathrm{~h}) \text {; } \\
\text { - Plasma O-methyl-isorhamnetin: } \\
\uparrow 46 \% \text { Cmax; } \\
\uparrow 43 \% \text { AUC }(0-24 \mathrm{~h}) .\end{array}$ & $\begin{array}{l}\text { Dietary fat improved } \\
\text { quercetin bioavailability by } \\
\text { increasing its absorption } \\
\text { leading to a possible dietary } \\
\text { approach for reducing } \\
\text { CVD risk. }\end{array}$ & {$[39]$} \\
\hline
\end{tabular}


Table 3. Cont.

\begin{tabular}{|c|c|c|c|c|c|}
\hline Cohort and Study Details & Flavonol Intake & Aim & Bioavailability Data & Outcome & Reference \\
\hline $\begin{array}{l}6 \text { heathy subjects } \\
(4 \mathrm{M} ; 2 \mathrm{~F}) \\
\text { (mean age } 34 \pm 7 \text { years) } \\
\text { Duration: } 1 \text { day } \\
\text { Randomized, double-blind, } \\
\text { crossover study }\end{array}$ & 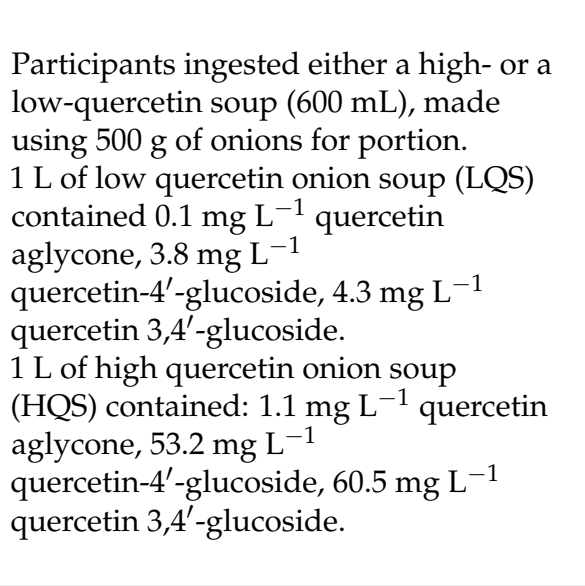 & $\begin{array}{l}\text { To investigate the possible } \\
\text { inhibitory effects of quercetin } \\
\text { ingestion from a dietary } \\
\text { source on platelet function } \\
\text { (collagen-stimulated platelet } \\
\text { aggregation and } \\
\text { collagen-stimulated tyrosine } \\
\text { phosphorylation). }\end{array}$ & $\begin{array}{l}\text { After HQS treatment, } \\
\text { plasma levels of quercetin did } \\
\text { the following: } \\
\text { - Peaked at } 2.59 \pm 0.42 \mathrm{mmol} \mathrm{L}^{-1} \\
(p=0.0001) ; \\
\text { - AUC } 911.61 \pm 85 \cdot 17 \mathrm{mmol} \mathrm{L}^{-1} \text { per } \\
\text { min }(p=0.001) \text {. } \\
\text { Plasma levels of isorhamnetin peaked } \\
\text { after } 2 \text { h at } 0.119 \pm 0.02 \mathrm{mmol} \mathrm{L}^{-1} \\
\text { (HQS) and } 0.0133 \pm 0.04 \mathrm{mmol} \mathrm{L}^{-1} \\
\text { (LQS) }(p=0.0001) \text {. } \\
\text { Plasma levels of tamarixetin peaked } \\
\text { after } 2.5 \mathrm{~h} \text { at } 0.172 \pm 0.035) \mathrm{mmol} \mathrm{L}^{-1} \\
(\mathrm{HQS}) \text { and } 0.0049 \pm 0.001 \mathrm{mmol} \mathrm{L}^{-1} \\
(\mathrm{LQS})(p=0.0001) .\end{array}$ & $\begin{array}{l}\text { HQS treatment inhibited the } \\
\text { following: } \\
\text { - Collagen-stimulated platelet } \\
\text { aggregation } \\
\text { (time-dependent); } \\
\text { - Collagen-stimulated } \\
\text { tyrosine phosphorylation } \\
\text { ( } p=0.001) . \\
\text { The inhibition of tyrosine } \\
\text { phosphorylation was } \\
\text { correlated with AUC of } \\
\text { quercetin after HQS intake. }\end{array}$ & [40] \\
\hline $\begin{array}{l}36 \text { healthy human subjects } \\
(16 \mathrm{M} ; 20 \mathrm{~F}) \text { (mean age: } \\
31.4 \pm 7.7 \text { years) } \\
\text { Duration: } 4 \text { weeks } \\
\text { Randomized crossover study }\end{array}$ & $\begin{array}{l}\text { Treatment period: high flavonol (HF) } \\
\text { diet based on daily consumption of } 150 \mathrm{~g} \\
\text { onion cake ( } 89.7 \mathrm{mg} \text { quercetin) }+300 \mathrm{~mL} \\
\text { black tea ( } 1.4 \mathrm{mg} \text { quercetin). Control } \\
\text { period: low flavonol (LF) period based } \\
\text { on exclusion of flavonol and flavone } \\
\text { foods and tea. }\end{array}$ & $\begin{array}{l}\text { To determine the effect of } \\
\text { dietary intake of quercetin } \\
\text { from onions and black tea on } \\
\text { oxidative damage to } \\
\text { leukocytes DNA bases. }\end{array}$ & $\begin{array}{l}\text { Plasma quercetin was }<\text { LOD } \\
\left(66.2 \mathrm{nmol} \mathrm{L}^{-1}\right) \text { after the HF period } \\
\text { and increased at } 228.5 \pm 34.7 \mathrm{nmol} \mathrm{L}^{-1} \\
\text { after HF period. }\end{array}$ & $\begin{array}{l}\text { The concentrations of the } \\
\text { products of oxidative damage } \\
\text { to DNA bases did not differ } \\
\text { significantly between the two } \\
\text { dietary treatment periods for } \\
\text { any of the products } \\
\text { measured. }\end{array}$ & [41] \\
\hline $\begin{array}{l}32 \text { healthy subjects (mean age } \\
30.4 \pm 7.3 \text { years) } \\
\text { Duration: } 4 \text { weeks } \\
\text { Randomized crossover study }\end{array}$ & $\begin{array}{l}\text { Treatment period: high flavonol (HF) } \\
\text { diet based on daily consumption of } 150 \mathrm{~g} \\
\text { onion cake ( } 89.7 \mathrm{mg} \text { quercetin) }+300 \mathrm{~mL} \\
\text { black tea ( } 1.4 \mathrm{mg} \text { quercetin). } \\
\text { Control period: low flavonol (LF) period } \\
\text { based on exclusion of flavonol and } \\
\text { flavone foods and tea. }\end{array}$ & $\begin{array}{l}\text { To investigate the effects of a } \\
\text { high-flavonoid (HF) diet on } \\
\text { markers of oxidative stress } \\
\text { (F2 -isoprostanes and } \\
\text { malondialdehyde } \\
\text { (MDA)-modified LDL) } \\
\text { compared with a } \\
\text { low-flavonoid (LF) diet. }\end{array}$ & $\begin{array}{l}\text { After the HF treatment, plasma } \\
\text { quercetin concentrations were } \\
\text { significantly higher }(221.6 \pm 37.4 \mathrm{nmol} \\
\left.\mathrm{L}^{-1}\right) \text { than after the } \mathrm{LF} \text { treatment } \\
(\text { compared with less than the LOD of } \\
\left.66.2 \mathrm{nmol} \mathrm{L}{ }^{-1}\right)\end{array}$ & $\begin{array}{l}\text { There were no significant } \\
\text { differences in plasma } \\
\text { F2-isoprostane } \\
\text { concentrations, and } \\
\text { MDA-LDL between the HF } \\
\text { and LF dietary treatments. }\end{array}$ & [42] \\
\hline
\end{tabular}


Table 3. Cont

\begin{tabular}{|c|c|c|c|c|c|}
\hline Cohort and Study Details & Flavonol Intake & Aim & Bioavailability Data & Outcome & Reference \\
\hline $\begin{array}{l}229 \text { healthy subjects (mean } \\
\text { age } 31.05 \pm 8.9 \text { years) } \\
\text { Duration: } 3 \text { months } \\
\text { Randomized double-blind, } \\
\text { placebo controlled study }\end{array}$ & $\begin{array}{l}\text { Participants consumed } 16.7 \mathrm{mg} / \text { day of } \\
\text { sea buckthorn extract or placebo, added } \\
\text { to } 28 \text { g of puree. } \\
\text { The daily dose of sea buckthorn } \\
\text { extract contained: } \\
\text { - } 5.8 \pm 0.7 \mathrm{mg} \text { isorhamnetin } \\
\text { 3-O-glucoside-7-O-rhamnoside; } \\
\text { - } 1.5 \pm 0.9 \mathrm{mg} \text { quercetin 3-Orutinoside; } \\
-1.6 \pm 0.4 \mathrm{mg} \text { quercetin 3-O-glucoside; } \\
\text { - } 5.1 \pm 0.8 \mathrm{mg} \text { isorhamnetin 3-O-rutinoside; } \\
-2.4 \pm 0.4 \mathrm{mg} \text { isorhamnetin 3-O-glucoside; } \\
-0.3 \pm 0.4 \mathrm{mg} \text { kaempferol 3-O-rutinoside. }\end{array}$ & $\begin{array}{l}\text { To study the effect of } \\
\text { flavonoid-rich sea buckthorn } \\
\text { berry on circulating lipid } \\
\text { markers associated with CVD } \\
\text { risk (total, HDL and LDL } \\
\text { cholesterol, triacylglycerols) } \\
\text { and CRP. }\end{array}$ & $\begin{array}{l}\text { The consumption of sea buckthorn } \\
\text { extract significantly modified the } \\
\text { plasma concentration in treated group: } \\
\uparrow \text { quercetin }\left(3.0 \mathrm{ng} \mathrm{mL}^{-1}, p=0.03\right) ; \\
\uparrow \text { isorhamnetin }\left(3.9 \mathrm{ng} \mathrm{mL}^{-1}, p<0.01\right) .\end{array}$ & $\begin{array}{l}\text { Sea buckthorn extract did not } \\
\text { affect serum concentration of } \\
\text { any CVD risk } \\
\text { factors considered. }\end{array}$ & [43] \\
\hline $\begin{array}{l}15 \text { healthy volunteers } \\
(6 \mathrm{M} ; 9 \mathrm{~F}) \\
\text { (mean age } 60.8 \pm 9.3 \text { years) } \\
\text { Duration: } 1 \text { week } \\
\text { Randomized, controlled, } \\
\text { crossover study }\end{array}$ & $\begin{array}{l}\text { Each subject received } 5 \text { doses of } \\
\text { quercetin-3-O-glucoside: } \\
\text { - } 0 \mathrm{mg} \text {; } \\
\text { - } 50 \mathrm{mg} ; \\
\text { - } 100 \mathrm{mg} ; \\
\text { - } 200 \mathrm{mg} ; \\
\text { - } 400 \mathrm{mg} \text {. } \\
\text { Each compound (control or treatment) } \\
\text { was provided once in the morning in a } \\
\text { cup of coffee. }\end{array}$ & $\begin{array}{l}\text { To determine whether } \\
\text { endothelial function, BP and } \\
\text { NO were affected in a } \\
\text { dose-dependent mode of } \\
\text { administration of } \\
\text { quercetin-3-O-glucoside. }\end{array}$ & $\begin{array}{l}\text { After the intake of increasing doses of } \\
\text { quercetin-3-O-glucoside, was observed: } \\
\uparrow \text { quercetin dose-dependent plasma } \\
\text { concentrations }\left(\mathrm{R}^{2}=0.52, p<0.001\right) \\
\uparrow \text { isorhamnetin dose-dependent } \\
\text { plasma concentrations }\left(\mathrm{R}^{2}=0.12\right. \\
p=0.005) \text {. } \\
\text { Baseline: } \\
\text { - free quercetin } 1.90 \pm 1.1 \mathrm{mM} \text {; } \\
\text { - isorhamnetin } 0.99 \pm 0.06 \mathrm{mM} \text {. }\end{array}$ & $\begin{array}{l}\text { After any intervention, no } \\
\text { improvements were } \\
\text { observed in: } \\
\text { - endothelial function, } \\
\text { - BP; } \\
\text { - NO production. }\end{array}$ & [47] \\
\hline $\begin{array}{l}6 \text { healthy subjects } \\
(4 \mathrm{M} ; 2 \mathrm{~F}) \\
\text { (mean age } 34 \pm 7 \text { years) } \\
\text { Duration: } 1 \text { day } \\
\text { Randomized } \\
\text { placebo-controlled } \\
\text { crossover study }\end{array}$ & $\begin{array}{l}\text { Participants were randomly treated with } \\
\text { the following: } \\
\text { - } 150 \mathrm{mg} \text { Q-4-G in 5\% ethanol; } \\
\text { - } 300 \mathrm{mg} \text { Q-4-G in 5\% ethanol; } \\
\text { - } 5 \%(v / v) \text { ethanol control drink. }\end{array}$ & $\begin{array}{l}\text { To investigate the effect of the } \\
\text { dietary ingestion of quercetin } \\
\text { on platelet function (platelet } \\
\text { aggregation and platelet } \\
\text { collagen-stimulated tyrosine } \\
\text { phosphorylation). }\end{array}$ & $\begin{array}{l}\text { Plasma concentrations peaked } 30 \mathrm{~min} \\
\text { after ingestion. } \\
\text { Group } 150 \mathrm{mg} \text { : } \\
\text { - Quercetin } 4.66 \pm 0.77 \mu \mathrm{M} ; \\
\text { - Isorhamnetin } 0.16 \pm 0.05 \mu \mathrm{M} ; \\
\text { - Tamarixetin } 0.24 \pm 0.07 \mu \mathrm{M} ; \\
\text { - Total flavonoid } 5.07 \pm 0.90 \mu \mathrm{M} \text {. } \\
\text { Group } 300 \mathrm{mg} \text { : } \\
\text { - Quercetin } 9.72 \pm 1.38 \mu \mathrm{M} ; \\
\text { - Isorhamnetin } 0.44 \pm 0.07 \mu \mathrm{M} ; \\
\text { - Tamarixetin } 0.54 \pm 0.09 \mu \mathrm{M}(\text { after } 45 \mathrm{~min}) ; \\
\text { - Total flavonoid } 10.66 \pm 1.55 \mu \mathrm{M} \text {. } \\
\text { These results indicating dose-dependent } \\
\text { bioavailability of flavonoid. }\end{array}$ & $\begin{array}{l}\text { After } 30 \text { and } 120 \text { min since } \\
\text { intake of both doses of Q-4-G } \\
\text { were inhibited: } \\
\text { - platelet aggregation } \\
(p=0.001) ; \\
\text { - collagen-stimulated tyrosine } \\
\text { phosphorylation of TPP } \\
(p=0.001) .\end{array}$ & [48] \\
\hline
\end{tabular}


Table 3. Cont.

\begin{tabular}{|c|c|c|c|c|c|}
\hline Cohort and Study Details & Flavonol Intake & Aim & Bioavailability Data & Outcome & Reference \\
\hline $\begin{array}{l}12 \text { healthy men } \\
\text { (mean age of } 43.2 \pm 4.3 \text { years) } \\
\text { Duration: acute consumption } \\
\text { Randomized, } \\
\text { placebo-controlled, } \\
\text { crossover trial }\end{array}$ & $\begin{array}{l}\text { Each participant received, in random } \\
\text { order, } 4 \text { treatments: } \\
\text { - } 300 \mathrm{~mL} \text { water (control); } \\
\text { - } 0.67 \mathrm{mg} / \mathrm{mL} \text { quercetin; } \\
\text { - } 0.67 \mathrm{mg} / \mathrm{mL} \text { epicatechin; } \\
\text { - } 0.67 \mathrm{mg} / \mathrm{mL} \text { EGCG. }\end{array}$ & $\begin{array}{l}\text { To evaluate the effects of } \\
\text { quercetin and epicatechin on } \\
\text { the endothelial function } \\
\text { (measuring endothelin-1 and } \\
\text { NO production) and } \\
\text { oxidative stress (measuring } \\
\text { urinary F2-isoprostanes). }\end{array}$ & $\begin{array}{l}\text { Acute treatment with quercetin and } \\
\text { epicatechin significantly increased } \\
(p<0.001) \text { the total circulating } \\
\text { concentration of each flavonoid (from } \\
0.84 \pm 0.39 \mu \mathrm{mol} \mathrm{L} \mathrm{L}^{-1} \text { to } \\
3.54 \pm 1.57 \mu \mathrm{mol} \mathrm{L}{ }^{-1} \text { for quercetin } \\
\text { and from and } 0.70 \pm 0.34 \mu \mathrm{mol} \mathrm{L} \mathrm{L}^{-1} \text { to } \\
3.57 \pm 1.21 \mu \mathrm{mol} \mathrm{L}{ }^{-1} \text { for epicatechin). } \\
\text { In urine, concentrations of total } \\
\text { quercetin increased from } 0.61 \pm 0.15 \text { to } \\
2.51 \pm 0.65 \mu \text { mol mmol }{ }^{-1} \text { creatinine } \\
\text { and total epicatechin from } 0.50 \pm 0.28 \\
\text { to } 2.62 \pm 0.98 \mu \mathrm{mol}^{-1} \mathrm{mmol}^{-1} \text { creatinine } \\
(p<0.001) \text {. Plasma concentrations of } \\
\text { EGCG increased from } 0.06 \pm 0.01 \text { to } \\
0.10 \pm 0.01 \mu \mathrm{mol} \mathrm{L}-1 \\
\text { was not detected in urine. }\end{array}$ & $\begin{array}{l}\text { EGCG did not affect NO } \\
\text { production. Quercetin and } \\
\text { epicatechin significantly } \\
\text { reduced plasma endothelin-1 } \\
\text { concentration }(p<0.05) \text {, but } \\
\text { only quercetin significantly } \\
\text { decreased the urinary } \\
\text { endothelin- } 1 \text { concentration. } \\
\text { None of the } 3 \text { treatments } \\
\text { significantly decreased } \\
\text { plasma or urinary } \\
\text { F2-isoprostane } \\
\text { concentrations. }\end{array}$ & [49] \\
\hline $\begin{array}{l}15 \text { healthy subjects } \\
(9 \mathrm{M} ; 6 \mathrm{~F}) \\
\text { (mean age } 25.8 \pm 5.2 \text { years) } \\
\text { Duration: } 3 \text { weeks } \\
\text { Double blind, randomized, } \\
\text { placebo-controlled trial. }\end{array}$ & $\begin{array}{l}\text { Subjects received a capsule containing } \\
\text { the following: } \\
\text { - Placebo; } \\
\text { - } 200 \mathrm{mg} \text { of quercetin; } \\
\text { - } 400 \mathrm{mg} \text { of quercetin. }\end{array}$ & $\begin{array}{l}\text { To evaluate whether the } \\
\text { deconjugation of } \\
\text { quercetin-3-O-glucuronide } \\
\text { (Q3GA) may improve } \\
\text { vasodilator effects of } \\
\text { quercetin. }\end{array}$ & $\begin{array}{l}\text { At } 2 \mathrm{~h} \text { post ingestion, plasma levels } \\
\text { were as follows: } \\
\text { - } 200 \mathrm{mg} \text { quercetin group: } 0.35 \mu \mathrm{M} \\
\text { Q3GA, } 0.043 \mu \mathrm{M} \text { quercetin aglycone, } \\
0.008 \mu \mathrm{M} \text { isorhamnetin aglycone, } \\
\text { - } 400 \mathrm{mg} \text { quercetin group: } 0.95 \mu \mathrm{M} \\
\mathrm{Q} 3 \mathrm{GA}, 0.031 \mu \mathrm{M} \text { quercetin aglycone, } \\
0.035 \mu \mathrm{M} \text { isorhamnetin aglycone. } \\
\text { Glucuronides of isorhamnetin were } \\
\text { not detected. }\end{array}$ & $\begin{array}{l}\text { After ingestion ( } 2 \text { or } 5 \mathrm{~h}) \text { of } \\
\text { both doses, were not changes } \\
\text { in systolic and diastolic blood } \\
\text { pressure. } \\
\text { A time-dependent increase in } \\
\text { brachial artery diameter was } \\
\text { detected after } 400 \mathrm{mg} \\
\text { quercetin intake, correlated } \\
\text { with the levels of Q3GA } \\
\text { mediated by } \\
\text { glucuronidase activity. }\end{array}$ & {$[50]$} \\
\hline
\end{tabular}

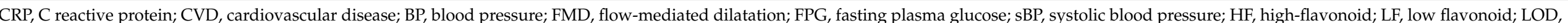

Limit of Detection; EGCG, Epigallocatechin gallate; Q-4-G, quercetin-4-O- $\beta$-glucoside; TPP, total platelet proteins. 
Despite the negative results, plasma flavonols (quercetin, kaempferol and isorhamnetin glucuronides, and sulfates) significantly increased after the treatment, with respect to placebo $(p<0.005)$. This means that the initial dose taken correlates closely with the biological effects but is not always explained by the bioavailability of flavonols and the duration of intake. In fact, although the flavonol plasma levels were always measurable, they were not sufficient to affect specific biomarkers. Quercetin, especially in its glucosidic form, is generally efficiently absorbed and bioavailable. In addition, quercetin metabolite elimination is quite low ( $\mathrm{t}_{1 / 2} 11-28 \mathrm{~h}$ ), leading to their accumulation in plasma with repeated intakes [20]. Positive results were obtained on FMD and platelet aggregation.

Bondonno et al. (2016) observed no improvement in blood pressure or FMD in healthy subjects, when increasing amounts of quercetin-3-O-glucoside (50-400 mg/day) were provided [47], but only when quercetin was enzymatically modified to obtain a more bioavailable $\alpha$-oligoglucosylated quercetin derivative, isoquercitrin. Supplementation with $4.89 \mathrm{mg}$ of this compound significantly increased FMD response by $1.8 \%$ compared with the placebo $(p=0.025)$, but with different mechanisms not involving NO production increase. In contrast, cognitive function was not affected. The different form of quercetin used makes it difficult to compare it with other studies; however, the maximum plasma concentration reached $144 \pm 12.3 \mathrm{nM}$, which is higher than the values measured in other studies where quercetin was administered $[48,49]$.

Perez et al. (2014) postulated that the vasodilator effects can be mediated by quercetin3-O-glucuronide (Q3GA) deconjugation mediated by plasmatic glucuronidase [50]. This is because a plasmatic dose-dependent increase in this metabolite was detected after 200 and $400 \mathrm{mg}$ supplementation with quercetin, which was not detected with other metabolites (quercetin aglycone, isorhamnetin aglycone, and their glucuronide forms). The enzyme glucuronidase is present in lysosomes involved in the glycosaminoglycans cleavage. An extensive inter-individual variability in the activity of glucuronidase has also been described, which may be attributed by variations in its gene sequence or expression. This enzyme hydrolyzes glucuronidated metabolites at the vascular level, producing the parent aglycone, which, due to its elevated liposolubility, accumulates in tissues and performing its biological activity. The effect on arterial diameter was not associated with either the early changes flavonoid plasmatic levels or the glucuronidase activity. Nevertheless, these effects were associated with a combination of both factors. Quercetin provided by food (high-quercetin onion soup) or supplements (providing 138 and $150 \mathrm{mg}$ quercetin, respectively) was shown to be effective in inhibiting platelet aggregation mediated by collagen. The inhibition correlated highly with the AUC of the quercetin metabolites, isorhamnetin and tamarixetin (4-O-methyl-quercetin) [40,48].

\subsection{Phenolic Acids}

Phenolic acids are a class of secondary metabolites, highly distributed among plants. According to their chemical structure, phenolic acids can be divided in benzoic and cinnamic acids. The main benzoic groups are gallic, protocatechuic, and $p$-hydroxybenzoic acids, mainly as conjugates. The highest concentration (fresh weight) of benzoic acids has been calculated in Apiaceae species (spices and herbs): anise $730-1080 \mathrm{mg} \mathrm{kg}^{-1}$, cumin up to $42 \mathrm{mg} \mathrm{kg}^{-1}$, fennel up to $106 \mathrm{mg} \mathrm{kg}^{-1}$, and parsley up to $30 \mathrm{mg} \mathrm{kg}^{-1}$ [51,52]. Cinnamic acids are widely distributed in plants, as esters or amides. The most representative are caffeic, chlorogenic, and ferulic acids. High concentrations of cinnamic acids are coffee, tea, wine, cocoa, fruits, vegetables, and cereals. Some of the most important sources of caffeic acid are wild blueberry $\left(1470 \mathrm{mg} \mathrm{kg}^{-1}\right)$, coffee $\left(870 \mathrm{mg} \mathrm{kg}^{-1}\right)$, carrots $\left(260 \mathrm{mg} \mathrm{kg}^{-1}\right)$, plum (234 $\left.\mathrm{mg} \mathrm{kg}^{-1}\right)$, and eggplant $\left(210 \mathrm{mg} \mathrm{kg}^{-1}\right)$.

One of the most important derivatives of caffeic acid is caftaric acid, a representative polyphenol in wine (6-73 $\mathrm{mg} \mathrm{L}^{-1}$ in white wine, $46-141 \mathrm{mg} \mathrm{L}^{-1}$ in red wine), while chlorogenic acid is present in considerable levels in coffee (depending on the climatic and processing conditions, and procedures for coffee preparation) $[53,54]$. The chlorogenic acid content in roasted coffee beans varies depending on the roasting extent, in the range 
of $2.3-80 \mathrm{~g} / \mathrm{kg}$ (dried weight) and $890-8130 \mathrm{mg} / \mathrm{L}$ in espresso coffee [53]. The intake of chlorogenic acid can be very high; it has been estimated to be up to $0.8 \mathrm{~g}$ per day among coffee drinkers [20].

Cereals are the most important source of ferulic acid, derivative of cinnamic acid derivative (for which the intake ranges from about 0.092 to $0.32 \mathrm{~g}$ ) [49]. Table 4 shows the studies correlating phenolic acid intake, their bioavailability, and different health effects, mainly focused on blood pressure, vasodilation, antioxidant activity, and inflammation. Six of ten studies included in this review investigated the effects of chlorogenic acid and its metabolites in coffee or in beverages prepared in order to mimic coffee intake; one study used purified caffeoylquinic acid (5-CQA); one study included whole grain; and two studies included a blueberry drink. Phenolic acids were administered to healthy subjects in the range of 138.7 and $900 \mathrm{mg} /$ day and were tested both in acute and chronic consumption (maximum eight weeks). Generally speaking, vascular function was positively affected by chlorogenic acid (CGA) provided by decaffeinated coffee intake $(50 \mathrm{~mL})$ or purified caffeoylquinic acid (5-CQA), confirming previous studies showing that phenolic compounds, other than caffeine, can contribute to vasoactive efficacy $[55,56]$. Observational studies indicate that moderate coffee intake (4 cups), containing from 105 to $500 \mathrm{mg}$ of CGA, is associated with a lower CVD risk [57].

Potential mechanisms by which CGA and its main plasma metabolites (5-cholorgenic acid, ferulic- $4^{\prime}$-O-sulfate, and isoferulic- $3^{\prime}$-O-glucuronide) mediate the vascular effects include the inhibition of NAPDH oxidase, leading to a reduction in superoxide production and, as a consequence, to an increase in endothelium NO bioavailability [58]. Conflicting positions have been taken regarding the possible agonistic or antagonist effects of caffeine on vascular function. Agudelo-Ochoa et al. (2016), postulated that caffeine could be responsible for the negative effects observed after $400 \mathrm{~mL}$ coffee intake (caffeine content $<300 \mathrm{mg}$ ), since it can interfere with the mechanism of action of chlorogenic acid, thus decreasing NO production [59]. In contrast, Boon et al. (2017) noticed a vasodilator effect only in subjects consuming caffeinated coffee ( $270 \mathrm{mg}$ caffeine) but not decaffeinated coffee, although the CGA levels were comparable (300 and $287 \mathrm{mg}$ CGA, respectively) [60]. In plasma, an increase in CGA metabolites (5-CGA) was always measured, even when no significant effects on vascular function were observed, suggesting that synergistic effects on different polyphenol compounds can occur. Rodriguez-Mateos et al. (2013) also observed an amelioration of endothelial function after the acute intake of blueberry drinks containing different levels of polyphenols, from 766 to $1791 \mathrm{mg}$ [61]. Phenolic acid metabolites (caffeic acid, ferulic acid, iso-ferulic acid, vanillic acid, benzoic acid, and 2-hydroxybenzoic acid) were the only ones measured in plasma, while no flavonols or anthocyanins were detected, thus suggesting that these compounds were not responsible for the positive effects noticed. The intake of phenolic acids with whole grains $(138 \mathrm{mg} / 70 \mathrm{~g})$ for eight weeks was associated with a reduced inflammatory status in overweight subjects by Vitaglione et al. (2015), compared with equal amounts of refined wheat (2.6 $\mathrm{mg}$ ferulic acid) [62]. 
Table 4. Phenolic acids' beneficial effects and bioavailability in human subjects.

\begin{tabular}{|c|c|c|c|c|c|}
\hline Cohort and Study Details & Phenolic Acids Intake & Aim & Bioavailability Data & Outcome & Reference \\
\hline $\begin{array}{l}1^{\circ} \text { study: } 15 \text { healthy male } \\
\text { subjects } \\
\text { (mean age: } 26.3 \pm 1.6 \text { years) } \\
2^{\circ} \text { study: } 24 \text { healthy male } \\
\text { subjects } \\
\text { (mean age: } 23.8 \pm 1.4 \text { years) } \\
\text { Duration: acute } \\
\text { consumption } \\
\text { Randomized controlled } \\
\text { crossover studies }\end{array}$ & $\begin{array}{l}1^{\circ} \text { study: Subjects consumed } 50 \mathrm{~mL} \\
\text { coffee containing high ( } 310 \mathrm{mg} \text { ) or } \\
\text { low }(89 \mathrm{mg} \text { ) chlorogenic acid levels. } \\
\text { Control intervention contained } 0 \\
\text { mg chlorogenic acid. } \\
2^{\circ} \text { study: Subjects consumed (a) } \\
0.45 \text { g purified } 5 \text {-caffeoylquinic } \\
\text { acid (5-CQA) + } 1 \text { g maltodextrin } \\
\text { (MDX); (b) } 0.90 \text { g purified 5-CQA + } \\
1 \text { g MDX; } 1 \text { g MDX (negative } \\
\text { control) and } 0.20 \text { g purified } \\
\text { epicatechin }+1 \text { g MDX (positive } \\
\text { control). Each preparation was } \\
\text { solubilized in } 200 \text { mL of hot water. }\end{array}$ & $\begin{array}{l}\text { To evaluate the vascular } \\
\text { function (\% flow-mediated } \\
\text { dilation, FMD) after the } \\
\text { consumption of coffee rich in } \\
\text { chlorogenic acid. }\end{array}$ & 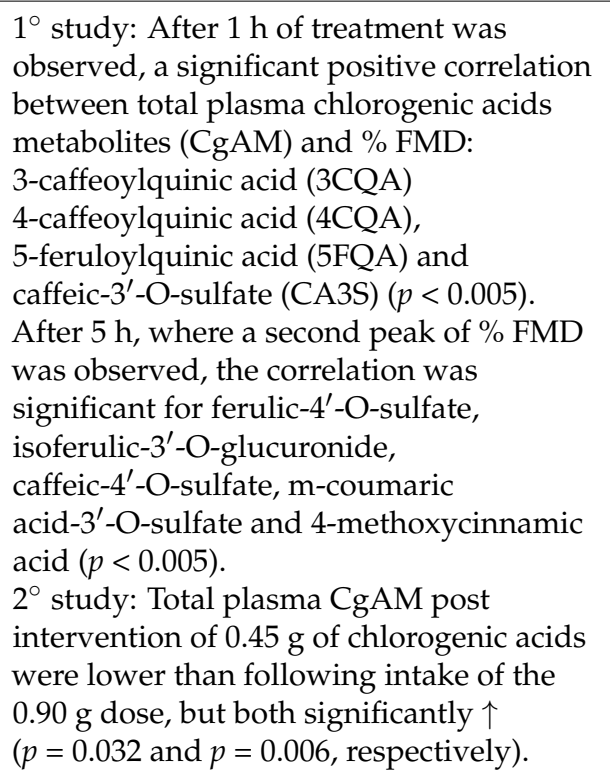 & $\begin{array}{l}1^{\circ} \text { study: Both low and high } \\
\text { chlorogenic enriched coffee } \\
\text { improved vascular function } \\
2^{\circ} \text { study: Only after the } 0.45 \mathrm{~g} \\
\text { dose of purified } 5 \text {-CQA, \%FMD } \uparrow \\
\text { in comparison to the water } \\
\text { control }(6.02 \pm 0.28 \text { to } 6.77 \pm 0.42, \\
p=0.06), \text { whereas intake of the } \\
\text { control (5.90 } \pm 0.33 \% \text { to } \\
5.86 \pm 0.30 \%) \text { or the higher dose } \\
\text { of } 5-\mathrm{CQA}(0.900 \mathrm{~g}) \text { had no effect } \\
\text { on } \% \text { FMD }(6.17 \pm 0.31 \% \text { to } \\
6.46 \pm 0.35 \%) .\end{array}$ & [55] \\
\hline $\begin{array}{l}23 \text { healthy subjects } \\
(4 \mathrm{M} ; 19 \mathrm{~F}) \text { (mean age: } \\
52.3 \pm 10.6 \text { years) } \\
\text { Duration: acute } \\
\text { consumption } \\
\text { Randomized, double-blind, } \\
\text { placebo-controlled, } \\
\text { crossover trial }\end{array}$ & $\begin{array}{l}\text { The treatments included: } \\
\text { - water (used as control); } \\
\text { - } 0.40 \mathrm{~g} \text { of chlorogenic acid } \\
\text { (3-O-caffeoylquinic acid) } \\
\text { solubilized in } 0.20 \mathrm{~L} \text { of water } \\
\text { (corresponding to } 2 \text { cups of coffee). }\end{array}$ & $\begin{array}{l}\text { To investigate the acute } \\
\text { effects of chlorogenic acid on } \\
\text { different parameters: } \\
\text { - Nitric oxide level; } \\
\text { - Endothelial function; } \\
\text { - Blood pressure. }\end{array}$ & $\begin{array}{l}\text { Chlorogenic acid concentration in plasma } \\
\text { was significantly higher } 150 \text { min after the } \\
\text { consumption of } 0.40 \mathrm{~g} \text { of CGA as } \\
\text { compared to control group ( } p<0.001 \text { ). } \\
\text { No significant differences were observed } \\
\text { in term of chlorogenic acid metabolites } \\
\text { (isoferulic acid, ferulic acid, phloretic acid, } \\
\text { caffeic acid, and hydrocaffeic acid) } \\
\text { between the two treatments. }\end{array}$ & $\begin{array}{l}\text { The mean systolic blood pressure } \\
(-2.41 \mathrm{mmHg}, p=0.05) \text { and } \\
\text { diastolic blood pressure } \\
(-1.53 \mathrm{mmHg}, p=0.04) \text { were } \\
\text { significantly } \downarrow \text { in the chlorogenic } \\
\text { acid group compared with } \\
\text { control group. NO levels } \\
(p>0.10) \text { and endothelial } \\
\text { function ( } p=0.60) \text { were not } \\
\text { significantly affected. }\end{array}$ & [56] \\
\hline
\end{tabular}


Table 4. Cont.

\begin{tabular}{|c|c|c|c|c|c|}
\hline Cohort and Study Details & Phenolic Acids Intake & Aim & Bioavailability Data & Outcome & Reference \\
\hline $\begin{array}{l}75 \text { healthy subjects ( } 38 \mathrm{M} \text {; } \\
37 \mathrm{~F} \text { (mean age: } \\
38.5 \pm 9 \text { years) } \\
\text { Duration: } 8 \text { weeks } \\
\text { Randomized, } \\
\text { placebo-controlled trial }\end{array}$ & $\begin{array}{l}\text { Group A: consumption } 400 \mathrm{~mL} \\
\text { coffee/day containing high levels } \\
\text { chlorogenic acids (HCCGA) } \\
\text { (780 mg/400 mL); group B: ( } 400 \mathrm{~mL} \\
\text { coffee/day containing medium } \\
\text { levels chlorogenic acid (MCCGA) } \\
\text { (420 mg/400 mL); group C: placebo. } \\
\text { Chlorogenic acids were composed } \\
\text { by: 5-O-caffeoylquinic; } \\
\text { 3-O-caffeoylquinic; } \\
\text { 4-O-caffeoylquinic; caffeic; ferulic; } \\
\text { 3,4-di-O-caffeoyl-quinic; } \\
\text { 3,5-di-O-caffeoylquinic; and } \\
\text { 4,5-di-O-caffeoylquinic. }\end{array}$ & $\begin{array}{l}\text { To evaluate the effects of } \\
\text { chlorogenic acids on the } \\
\text { following: } \\
\text { - The antioxidant capacity } \\
\text { of plasma; } \\
\text { - The lipid profile in serum; } \\
\text { - The vascular function } \\
\text { (flow-mediated dilation-FMD, } \\
\text { nitric oxide levels, blood } \\
\text { pressure). }\end{array}$ & $\begin{array}{l}\text { The concentration of ferulic and caffeic } \\
\text { acid was } \uparrow \text { in the groups that consumed } \\
\text { coffee-drinking and were significantly } \\
\text { higher } 1 \text { h after the consumption in the } \\
\text { MCCGA group than the HCCGA group } \\
\text { (caffeic acid: } 50.5 \pm 6.9 \mathrm{nM} \text { vs } 20.3 \pm 3.3 \\
\text { nM; ferulic acid: } 201 \pm 18.7 \mathrm{nM} \text { vs. } \\
137 \pm 6.1 \text { ) }(p<0.001 \text { ). In both groups the } \\
\text { ferulic and caffeic acids decreased after } \\
8 \text { weeks. }\end{array}$ & $\begin{array}{l}\text { Plasma antioxidant capacity } \\
\text { significantly increased only in the } \\
\text { group consuming medium levels } \\
\text { of chlorogenic acid }(6 \%) \text { and } \\
\text { group consuming high levels } \\
\text { chlorogenic acids }(5 \%)(p<0.05) . \\
\text { No effects on lipid profile and } \\
\text { vascular function were measured. }\end{array}$ & [59] \\
\hline $\begin{array}{l}16 \text { healthy subjects } \\
(10 \mathrm{~F}, 6 \mathrm{M}) \\
\text { (mean age: } 59.9 \pm 8.2 \text { years) } \\
\text { Duration: acute } \\
\text { consumption } \\
\text { Double-blind, randomized, } \\
\text { placebo-controlled } \\
\text { crossover study }\end{array}$ & $\begin{array}{l}\text { Subjects received: (1) } 0 \text { g purified } \\
\text { 5-chlorogenic acid (p5-CgA) } \\
\text { (control group); (2) } 0.45 \mathrm{~g} \text { p5-CgA; } \\
\text { (3) } 0.90 \mathrm{~g} \text { p5-CgA; and (4) } 0.20 \mathrm{~g} \\
\text { purified (-)-epicatechin (positive } \\
\text { control). Each treatment was } \\
\text { prepared in } 200 \mathrm{~mL} \text { of warm water } \\
\text { and consumed within } 10 \text { min. A } \\
\text { minimum one-week washouts } \\
\text { between visits was required. }\end{array}$ & $\begin{array}{l}\text { To evaluate the acute effect of } \\
\text { two doses of (5-CgA) }(0.45 \\
\text { and } 0.90 \text { g) on vascular } \\
\text { function (FMD) and blood } \\
\text { pressure. }\end{array}$ & $\begin{array}{l}\text { After } 1 \mathrm{~h} \text { and } 4 \mathrm{~h} \text { from the consumption of } \\
0.90 \mathrm{~g} 5-\mathrm{CgA} \text {, total } \mathrm{CgA} \text { metabolites, } \\
\text { reached } 1.5 \mu \mathrm{M} \text { and } 1.25 \mu \mathrm{M} \text {, respectively. } \\
\text { After } 0.45 \mathrm{~g} \text {, metabolites reached } 0.75 \mu \mathrm{M} \\
\text { and } 1 \mu \mathrm{M} \text { after } 1 \text { and } 4 \mathrm{~h} \text {, respectively. In } \\
\text { both cases, the most representative CgA } \\
\text { metabolite was 5-caffeoylquinic acid } \\
\text { (5-CqA). }\end{array}$ & $\begin{array}{l}\text { None of the doses of } 5-\mathrm{CgA} \text { used } \\
\text { significantly affected FMD } \\
\text { response. }\end{array}$ & [63] \\
\hline $\begin{array}{l}12 \text { healthy subjects } \\
(5 \mathrm{~F}, 7 \mathrm{M}) \\
\text { (mean age: } 59.4 \pm 6.4 \text { years) } \\
\text { Duration: acute } \\
\text { consumption } \\
\text { Randomized, } \\
\text { placebo-controlled, } \\
\text { crossover trial }\end{array}$ & $\begin{array}{l}\text { Subjects consumed: (1) } 18 \mathrm{~g} \text { of } \\
\text { ground caffeinated coffee }+0.3 \mathrm{~g} \\
\mathrm{CgA} \text { in } 0.20 \mathrm{~L} \text { of hot water; }(2) 18 \mathrm{~g} \\
\text { of decaffeinated coffee }+0.287 \mathrm{~g} \\
\mathrm{CgA} \text { in } 0.20 \mathrm{~L} \text { of hot water; (3) } \\
0.20 \mathrm{~L} \text { of hot water (control). For } \\
\text { each group the beverages were } \\
\text { consumed twice. The second } \\
\text { beverage was consumed after } 2 \mathrm{~h} \\
\text { with a } 75 \mathrm{~g} \text { glucose load. }\end{array}$ & $\begin{array}{l}\text { The aim of the study was to } \\
\text { evaluate the effect of coffee } \\
\text { on different outcomes: } \\
\text { (1) vascular function (FMD), } \\
\text { (2) blood pressure, (3) glucose } \\
\text { concentration in blood. }\end{array}$ & $\begin{array}{l}\text { The mean values concentration for } 5-\mathrm{CgA} \\
\text { were: } \\
\text { - caffeinated group: } 1.89 \pm 0.56 \mathrm{nM} \text {; } \\
\text { - water group: } 1.21 \pm 0.22 \mathrm{nM} ; \\
\text { - decaffeinated group: } 1.30 \pm 0.29 \mathrm{nM} \text {. } \\
\text { No significant difference in } 5-\mathrm{CgA} \\
\text { concentration between the three groups } \\
\text { were observed. }\end{array}$ & $\begin{array}{l}\text { The FMD response was } \\
\text { significantly } \uparrow \text { in the caffeinated } \\
\text { coffee group compared to the } \\
\text { other groups (decaffeinated } \\
\text { coffee and water) }(p<0.001) \text {. No } \\
\text { significant difference in the FMD } \\
\text { response between decaffeinated } \\
\text { coffee and water groups was } \\
\text { observed. No differences were } \\
\text { observed in term of blood } \\
\text { glucose concentrations and blood } \\
\text { pressure between the three } \\
\text { groups considered. }\end{array}$ & [60] \\
\hline
\end{tabular}


Table 4. Cont.

\begin{tabular}{|c|c|c|c|c|c|}
\hline Cohort and Study Details & Phenolic Acids Intake & Aim & Bioavailability Data & Outcome & Reference \\
\hline $\begin{array}{l}68 \text { healthy } \\
\text { overweight/obese subjects } \\
(23 \mathrm{M} ; 45 \mathrm{~F}) \\
\text { (mean age: } 38.5 \pm 2 \text { years) } \\
\text { with sedentary lifestyle } \\
\text { and reduced intake of fruit } \\
\text { and vegetables } \\
\text { Duration: } 8 \text { weeks } \\
\text { Randomized } \\
\text { placebo-controlled, } \\
\text { randomized trial }\end{array}$ & $\begin{array}{l}\text { Whole grain (WG) group } \\
\text { consumed } 70 \mathrm{~g} \text { wheat/day } \\
\text { containing } 96.7 \mathrm{mg} \text { ferulic acid, } \\
26.5 \mathrm{mg} \text { sinapic acid, } 9.4 \mathrm{mg} \\
\text { coumaric acid, } 1.9 \mathrm{mg} \text { gallic acid, } \\
1.8 \mathrm{mg} \text { syringic acid, } 1.6 \mathrm{mg} \text { vanillic } \\
\text { acid, } 0.5 \mathrm{mg} \text { salicylic acid, } 0.3 \mathrm{mg} \\
\text { caffeic acid); control group (CTR) } \\
\text { consumed } 60 \text { g refined wheat (RW) } \\
\text { products/day containing } 2.6 \mathrm{mg} \\
\text { ferulic acid. }\end{array}$ & $\begin{array}{l}\text { To investigate the role of } \\
\text { whole grain (WG) } \\
\text { consumption on plasma } \\
\text { markers of metabolic disease } \\
\text { and inflammation (tumor } \\
\text { necrosis factor- } \alpha \text { (TNF- } \alpha \text { ) } \\
\text { interleukin-10 (IL)-10), } \\
\text { plasminogen activator } \\
\text { inhibitor } 1 .\end{array}$ & $\begin{array}{l}\text { After } 8 \text { weeks, WG consumption was } \\
\text { associated with a } 4 \text {-fold } \uparrow \text { in serum } \\
\text { dihydroferulic acid (DHFA) and a 2-fold } \uparrow \\
\text { in fecal ferulic acid (FA) compared with } \\
\text { RW group. Similarly, after } 8 \text { weeks, } \\
\text { urinary FA was } 2 \text {-fold } \uparrow \text { the baseline } \\
\text { concentration only in WG group. }\end{array}$ & $\begin{array}{l}\text { In the WG group was observed a } \\
\downarrow \text { in TNF- } \alpha \text { after } 8 \text { weeks and } \uparrow \\
\text { IL-10 only after } 4 \text { weeks, } \\
\text { compared with RW group } \\
(p=0.04) \text {. No significant } \\
\text { differences in plasma metabolic } \\
\text { disease markers were observed. }\end{array}$ & [62] \\
\hline $\begin{array}{l}47 \text { habitual coffee drinkers } \\
\text { at risk for type- } 2 \text { diabetes } \\
(11 \mathrm{M} ; 36 \mathrm{~F}) \\
\text { (mean age } 54.0 \pm 9.0 \text { years) } \\
\text { Duration: } 3 \text { months } \\
\text { Crossover clinical trial }\end{array}$ & $\begin{array}{l}\text { The coffee consumption during the } \\
\text { trial was set as follow: } \\
\text { - First month: subjects avoided to } \\
\text { drink coffee; } \\
\text { - Second month: subjects consumed } \\
4 \text { cups ( } 150 \mathrm{~mL} / \text { cup) of filtered } \\
\text { coffee/day; } \\
\text { - Third month: participants } \\
\text { consumed } 8 \text { cups of filtered } \\
\text { coffee/day. }\end{array}$ & $\begin{array}{l}\text { To evaluate the role of daily } \\
\text { coffee consumption on the } \\
\text { following: } \\
\text { - The modulation of different } \\
\text { biomarkers of inflammation } \\
\text { (interleukin-18 (IL-18), } \\
\text { 8-isoprostane, and } \\
\text { adiponectin); } \\
\text { - Oxidative stress and glucose; } \\
\text {-Lipid metabolism. }\end{array}$ & $\begin{array}{l}\text { Positive correlations between the } \uparrow \text { in } \\
\text { serum concentrations of coffee phenolic } \\
\text { acid metabolites (cPAM) and changes in } \\
\text { adiponectin concentrations were detected } \\
\text { after } 8 \text { cups coffee/day consumption vs. } \\
\text { baseline ( } 0 \text { cups coffee/day). Significant } \\
\text { correlations were observed for isoferulic } \\
\text { acid ( } r=0.328, p=0.025) \text { and } \\
\text { dihydroisoferulic acid }(r=0.323, p=0.027) \text {. } \\
\text { Negative or no correlation was observed } \\
\text { for the other cPAM. }\end{array}$ & $\begin{array}{l}\text { Significant differences were } \\
\text { observed for serum } \\
\text { concentrations of IL-18, } \\
\text { 8-isoprostane, only after } 8 \text { cups } \\
\text { coffee/day consumption } \\
\text { compared with baseline ( } 0 \text { cups } \\
\text { coffee/day). Serum } \\
\text { concentrations of total } \\
\text { cholesterol, HDL cholesterol, and } \\
\text { apolipoprotein A-I } \uparrow \text { significantly } \\
\text { (+12\%, } 7 \% \text {, and } 4 \% \text {, respectively). } \\
\text { The ratios of LDL to HDL } \\
\text { cholesterol and of apolipoprotein } \\
\text { B to apolipoprotein A-I } \\
\text { significantly } \downarrow \text { ( }-8 \% \text { and } 9 \% \text {, } \\
\text { respectively) after the } \\
\text { consumption of } 8 \text { cups } \\
\text { coffee/day compared with } \\
0 \text { cups coffee/day. No variations } \\
\text { were observed for glucose } \\
\text { metabolism markers. }\end{array}$ & [64] \\
\hline
\end{tabular}


Table 4. Cont

\begin{tabular}{|c|c|c|c|c|c|}
\hline Cohort and Study Details & Phenolic Acids Intake & Aim & Bioavailability Data & Outcome & Reference \\
\hline $\begin{array}{l}20 \text { healthy subjects } \\
(6 \mathrm{M} ; 14 \mathrm{~F}) \text { (mean age: } \\
35.7 \pm 9.0 \text { years) } \\
\text { Duration: acute } \\
\text { consumption } \\
\text { Randomized } \\
\text { placebo-controlled trial }\end{array}$ & $\begin{array}{l}\text { 0.4 L of Arabica coffee containing } \\
0.42 \text { g CgAs ( } 6 \text { g/100 mL: provided } \\
105 \pm 4.1 \text { mg of CgAs) were given } \\
\text { to the intervention group } \\
\text { The sum of the following acids } \\
\text { contributed to the total CgAs and } \\
\text { phenolic acids content: } \\
\text { 5-O-caffeoylquinic; } \\
\text { 3-O-caffeoylquinic; } \\
\text { 4-O-caffeoylquinic; caffeic; ferulic; } \\
\text { 3,4-di-O-caffeoylquinic; } \\
\text { 3,5-di-O-caffeoylquinic; and } \\
\text { 4,5-di-O-caffeoylquinic. No coffee } \\
\text { or placebo were consumed by the } \\
\text { control group. }\end{array}$ & $\begin{array}{l}\text { The caffeic acid (CA) and } \\
\text { ferulic acid (FA) were } \\
\text { quantify and different } \\
\text { methods were applied to } \\
\text { evaluate the antioxidant } \\
\text { capacity of plasma. }\end{array}$ & $\begin{array}{l}\text { The concentrations of FA and CA, } \\
\text { measured } 1 \mathrm{~h} \text { after the coffee consumption, } \\
\text { were: } 202.38 \pm 12.87 \mathrm{nM} \text { and } \\
49.76 \pm 6.44 \mathrm{nM} \text {, respectively. } \\
\text { Both acids (CA and FA) were not detected } \\
\text { at baseline. } \\
\text { In the control group, at } 1 \mathrm{~h} \text {, the same trend } \\
\text { was observed. }\end{array}$ & $\begin{array}{l}\text { The antioxidant capacity of } \\
\text { plasma was measured with ferric } \\
\text { reducing antioxidant power } \\
\text { assay (FRAP) and oxygen radical } \\
\text { absorbance capacity assay } \\
\text { (ORAC). Compared to the } \\
\text { baseline, the antioxidant capacity, } \\
\text { measured with both methods, } \uparrow \\
\text { significantly ( }+6.67 \% ; p<0.001 \\
\text { for FRAP and }+7.16 \% ; p<0.05 \text { for } \\
\text { ORAC). A correlation was } \\
\text { observed between the } \uparrow \text { of } \\
\text { antioxidant capacity and the plasma } \\
\text { concentration of FA and CA. }\end{array}$ & [65] \\
\hline
\end{tabular}

21 healthy men (mean age: $27 \pm 1.3)$

Duration: acute consumption Randomized, controlled, double-blind, crossover human- intervention trials $1^{\circ}$ study: participants consumed:

- A blueberry drink containing:

$0.766,1.278$, and $1.791 \mathrm{~g}$ total

blueberry polyphenols

(corresponding to $0.24,0.40$, and

$0.56 \mathrm{~kg}$ fresh blueberries,

respectively);

- Control drink (macronutrient and micronutrient drink)

$2^{\circ}$ study: participants consumed

the following:

- A blueberry drink containing

$0.319,0.637,0.766,1.278$ and

$1.791 \mathrm{~g}$ total blueberry polyphenols

(corresponding to $0.10,0.20,0.24$,

0.40 , and $0.56 \mathrm{~kg}$ fresh blueberries,

respectively);

Control drink (macronutrient and

micronutrient drink).
A correlation between the FMD $\uparrow$ and the

plasma concentration $\uparrow$ of different

phenolic acid metabolites (ferulic acid

isoferulic acid, vanillic acid,

2-hydroxybenzoic acid, benzoic acid, and

caffeic acid-sum of conjugated and

nonconjugated compounds) were

The endothelial function

(FMD) was monitored and

the time-dependent $\left(1^{\circ}\right.$

observed 2 and $6 \mathrm{~h}$ after consumption.

The phenolic acid metabolites were

( $2^{\circ}$ study) changes were

investigated. significantly $\uparrow$ at $1-2 \mathrm{~h}$ after blueberry polyphenol consumption $(p<0.001)$. The plasma total concentration of metabolites was about $400 \mathrm{nmol} / \mathrm{L}$ (coinciding with the highest FMD value at $1 \mathrm{~h}$ ).

The metabolites of flavanol or anthocyanin were not detected in plasma at any time after the intake of blueberry drink.
The consumption of $0.10-0.24 \mathrm{~kg}$

blueberry (corresponding to $0.319,0.639$ and $0.766 \mathrm{~g}$ total polyphenols) positively affected 
Considering the bioavailability data, this effect was mainly associated with ferulic acid, whose concentrations were two-fold higher in the feces of subjects consuming whole grains. Interestingly, this result was explained by the fact that the release of FA in the colon could be due to wheat bran polysaccharide fermentation and mediated by bacterial enzymes xylanase and ferulic acid esterase. These enzymes are mainly synthetized by Lactobacilli (Firmicutes), Bifidobacteria (Actinobacteria), Bacteroides, and Prevotella (Bacteroidetes) when arabinoxylans with esterified ferulic acids are introduced $[66,67]$. Since overweight or obese individuals show reduced amounts of Bacteroidetes and Bifidobacteriales, Firmicutes are considered the main responsible for the fermentation of whole-grain polysaccharides and ferulic acid liberation $[62,66]$.

\subsection{Stilbenes, Isoflavones, and Flavanones}

Only a few studies were found correlating the effects of stilbenes (resveratrol), isoflavones, and flavanones with their bioavailability (Table 5). Resveratrol is a phytoalexin that is widely distributed in the plant kingdom. It is found in more than 70 species, but grapes and wine are the most important sources. The mean levels of total resveratrol in red wine is $7 \mathrm{mg} \mathrm{L}^{-1}$; rose wine has a total of $2 \mathrm{mg} \mathrm{L}^{-1}$, and white wine has and $0.5 \mathrm{mg} \mathrm{L}^{-1}$ [60]. Resveratrol supplementation (250-500 mg/day for 7 and 28 days, respectively) was investigated in healthy subjects as regards cognitive function and cerebral ematic circulation. Despite total resveratrol metabolites (resveratrol $4^{\prime}$ glucuronide, $3^{\prime}$ glucuronide, and sulfate) being ten-fold higher in the treatment group, supplementation failed to improve cognitive function but increased cerebral flow and reduced fatigue levels [68,69]. These effects could also be mediated by unmetabolized resveratrol, since the literature data indicate that it can be found in plasma bound to albumin or LDL, and that it elicits its biological function after interaction with cells that have receptors for albumin and LDL [70]. In brain, resveratrol contributed to vasorelaxation, oxygenation, and sirtuin (SIRT)-mediated increases in mitochondrial gene expression in brain [68]. 
Table 5. Stilbenes', isoflavones', and flavanones' beneficial effects and bioavailability in human subjects.

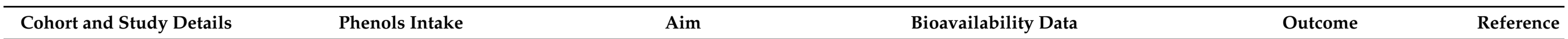

\section{- $\quad$ Stilbenes}

60 subjects $(9 \mathrm{M} ; 51 \mathrm{~F})$

(mean age: 20.52 years)

Duration: 28 days

placebo-controlled,

parallel-groups study

\section{2 healthy subjects}

(4 M; $20 \mathrm{~F})$

(mean age: 20.17 years)

Duration: 7 days

$\begin{array}{ll}\text { Randomized, double-blind, } & -250 \mathrm{mg} \text { trans-resveratrol; } \\ \text { placebo-controlled, } & -500 \mathrm{mg} \text { trans-resveratrol; }\end{array}$

crossover study trans-resveratrol (also containing

$500 \mathrm{mg} /$ day of pure

placebo.
To evaluate the effect of resveratrol on cognitive performance (measured as serial subtractions, rapid visual information processing, 3 Back test), mood, sleep quality and cerebral blood flow (CBF).

To evaluate the effects of oral resveratrol on cognitive performance and CBF. In a separate group $(n=9)$ was investigated plasma levels of resveratrol and its conjugates after the intake of the same treatments.
Resveratrol 3-O-sulfate was the predominant metabolite in all volunteers, contributing $73-77 \%$ of total metabolites, followed by resveratrol $4^{\prime}$ glucuronide and $3^{\prime}$ glucuronide. Total resveratrol metabolites increased in plasma from 3 to

$13 \mu \mathrm{M} 110 \mathrm{~min}$ after administration.

Resveratrol sulfate and glucuronide were the main metabolites and reached a peak plasma concentration at $90 \mathrm{~min}$ after both 250 and $500 \mathrm{mg}$ supplementation. As regards unmetabolized resveratrol, $90 \mathrm{~min}$ after both supplementations, reached low concentrations, peaking at 5.65 and $14.4 \mathrm{ng} \mathrm{mL}^{-1}$, respectively.
Although stilbene metabolite levels increase in plasma,

supplementing with $500 \mathrm{mg}$ of resveratrol for 28 days did not improve cognitive function.

\section{CBF increased in a}

dose-dependent fashion of resveratrol intake during task performance. No changes in cognitive function were registered.

\section{- Isoflavones}

Subjects consumed a high-fat,

high-fructose breakfast with 4 dietary supplementations:

- Placebo: fish oil placebo and isoflavone placebo;

10 overweight or obese men (mean age: $56.2 \pm 6.18$ years) Duration: acute consumption Randomized, double-blind, placebo-controlled, crossover study
- FO: fish oil and isoflavone placebo; - ISO: fish oil placebo and isoflavones - FO + ISO: fish oil and isoflavones. The soy isoflavone supplements provided $150 \mathrm{mg}$ glycoside isoflavones (eq. to $96 \mathrm{mg}$ aglycone form) in proportions of 1.05/1.0/0.29 for genistein/daidzein/glycitein. Fish oil supplement $(1 \mathrm{~g}$ of refined fish oil concentrate) providing $0.4 \mathrm{~g}$ EPA and $0.2 \mathrm{~g}$ DHA.
To evaluate the effect of acute supplementation with fish oil (n-3), PUFA, soy isoflavones, and their combination on postprandial serum triglycerides (TG) and oxidative biomarkers in proatherogenic high-fat, high-fructose meal.
At $4 \mathrm{~h}$, postprandially serum concentration was as follows: - Genistein

ISO: $1.027 \pm 0.122 \mu \mathrm{mol} \mathrm{L}^{-1}$,

FO + ISO: $1.185 \pm 0.079 \mu \mathrm{mol} \mathrm{L}^{-1}$

- Daidzein

ISO: $0.838 \pm 0.096 \mu \mathrm{mol} \mathrm{L}^{-1}, \mathrm{FO}+\mathrm{ISO}$ :

$1.017 \pm 0.046 \mu \mathrm{mol} \mathrm{L}^{-1}$.
The high-fat, high-fructose meal significantly increased serum total

FA and TG without affecting oxidative stress biomarkers. Serum TG and oxidative stress biomarkers did not differ between treatments. The FO and ISO were bioavailable but did not reduce the postprandial rise in serum TG.

Neither the study meal nor the FO or ISO induced significant changes in oxidative stress. 
Table 5. Cont.

\begin{tabular}{|c|c|c|c|c|c|}
\hline Cohort and Study Details & Phenols Intake & Aim & Bioavailability Data & Outcome & Reference \\
\hline $\begin{array}{l}78 \text { postmenopausal } \\
\text { osteopenic women } \\
\text { (mean age: } 61.85 \pm 1.03 \text { years) } \\
\text { Duration: } 12 \text { months } \\
\text { Double-blind, parallel design, } \\
\text { placebo-controlled trial }\end{array}$ & $\begin{array}{l}\text { Participants received } \\
\text { supplementation: } 1.2 \mathrm{~g} / \text { day } \\
\text { calcium, } 0.55 \mathrm{~g} / \text { day magnesium, } \\
0.025 \mathrm{~g} / \text { day calcitriol, and a red } \\
\text { clover extract }(0.06 \mathrm{~g} / \text { day } \\
\text { isoflavone aglycones and } \\
\text { probiotics) or a placebo. }\end{array}$ & $\begin{array}{l}\text { To determine the beneficial } \\
\text { effects of a bioavailable } \\
\text { isoflavone and probiotic } \\
\text { treatment in postmenopausal } \\
\text { osteopenia. }\end{array}$ & $\begin{array}{l}\text { After } 12 \text { month, isoflavone concentration } \\
\text { in the treated group was } 3.933 \mu \mathrm{gL} \mathrm{mL}^{-1} \\
\text { (median), significantly higher from } \\
\text { baseline }(p=0.0094) \text { (compared with the } \\
\text { control group, where median values were } \\
\left.2.323 \mu \mathrm{g} \mathrm{mL}^{-1}\right) \text {. }\end{array}$ & $\begin{array}{l}\text { Treatments with red } \\
\text { clover extract: } \\
\downarrow \text { BMD loss, } \\
\downarrow \text { plasma concentrations of } \\
\text { collagen type } 1 \text { crosslinked } \\
\text { C-telopeptide }(p<0.05)\end{array}$ & [72] \\
\hline $\begin{array}{l}237 \text { women } \\
\text { (mean age: } 53 \pm 3 \text { years) } \\
\text { Duration: } 12 \text { months } \\
\text { Randomized, double-blind, } \\
\text { placebo-controlled, parallel, } \\
\text { multicenter trial (including } \\
\text { the Netherlands, Italy } \\
\text { and France) }\end{array}$ & $\begin{array}{l}\text { Subjects, during their habitual diet } \\
\text { and lifestyle, consumed } 110 \\
\text { mg/day isoflavone aglycones } \\
\text { or control. }\end{array}$ & $\begin{array}{l}\text { To evaluate whether bone } \\
\text { metabolism and mineral } \\
\text { density, and hormonal } \\
\text { conditions were affected by } \\
\text { chronic consumption of } \\
\text { isoflavone-enriched foods. }\end{array}$ & $\begin{array}{l}\uparrow \text { isoflavones plasma levels in treated } \\
\text { group. Both genistein and daidzein were } \\
\text { higher in the Netherlands ( } 1522 \pm 1136.2 \\
\mathrm{nmol} \mathrm{L}-1 \text { and } 338.2 \pm 261.3 \mathrm{nmol} \mathrm{L}-1 \\
\text { respectively) than in France }(533.4 \pm 607.4 \\
\text { nmol L } \mathrm{L}^{-1} \text { and } 92.9 \pm 145.8 \mathrm{nmol} \mathrm{L}-1 \\
\text { respectively) and Italy ( } 541.5 \pm 557.6 \mathrm{nmol} \mathrm{L}^{-1} \\
\text { and } 133.4 \pm 188.3 \mathrm{nmol} \mathrm{L}^{-1} \text {, respectively). }\end{array}$ & $\begin{array}{l}\text { Bone mineral density or } \\
\text { biomarkers of bone were not } \\
\text { affected by isoflavone-enriched } \\
\text { products chronic intake. } \\
\text { Hormone concentrations did not } \\
\text { differ between the two groups. }\end{array}$ & [73] \\
\hline
\end{tabular}

\section{- Flavanones}

\section{6 men}

at moderate CVD risk

(mean age: $60.6 \pm 1.4$ years) Participants received $767 \mathrm{~mL}$

Duration: acute

consumption

Randomized

placebo-controlled

crossover trial orange juice or a hesperidin

C) or control.
To evaluate the effects of orange juice or a hesperidin supplement on plasma

concentrations of flavanone metabolites and their effects on cardiovascular risk supplement (both providing 320 $\mathrm{mg}$ hesperidin and $439 \mathrm{mg}$ vitamin endothelial function, central biomarkers (blood pressure arterial stiffness, cardiac autonomic function, platelet activation, and NADPH oxidase gene expression)

\section{After $5 \mathrm{~h}$ from the orange juice intake,}

significantly increased plasma

concentrations of 8 flavanones $(1.75 \pm 0.35$

$\left.\mathrm{mmol} \mathrm{L}^{-1}, p<0.0001\right)$, and 15 other

phenolic metabolites $\left(13.27 \pm 2.22 \mathrm{mmol} \mathrm{L}^{-1}\right.$,

$p<0.0001)$ were significantly increased.

In particular,

$47 \%$ hesperidin-glucuronide, $15 \%$

naringenin-7-O-glucuronide, $14 \%$ a second

hesperidin-glucuronide, $54 \%$ hippuric

acid, $15 \%$ dihydroferulic acid, $8 \%$

dihydroferulic acid-glucuronide, $7 \%$

4-hydroxyphenylacetic acid, and 5\%

vanillic acid increase were detected.
Effects on CVD risk factor were not observed.

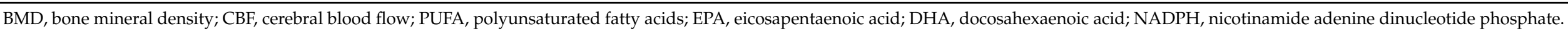


The only source of isoflavones are products derived from soybeans. Depending on the kind of soy preparation, isoflavones can be present as aglycones or glycosides. One study evaluated the impact of isoflavones on triglycerides and oxidative biomarkers [71]. Only two studies investigated the effects of isoflavones (supplemented for 12 months at doses of 60 and $96 \mathrm{mg}$ isoflavone aglycones/day, respectively) on bone density in post-menopausal women with contradictory results. In the study by Lambert et al. (2017), the positive effects were explained by the use of lactic acid probiotic bacteria in the treatment group in association with isoflavones, which mediated equol production [72]. Equol is a derivative of daidzein produced by anaerobic bacteria with great estrogenic potential. Since none of the subjects was able to produce equol at the beginning of the study and, after six months of treatment, $55 \%$ of individuals in the Red Clover Extract (RCE) group produced equol, it is plausible that that the probiotics positively affected the participant intestinal bacterial pattern, promoting more positive conditions for equol production. This hypothesis seems to be confirmed by the fact that high plasma levels were found in both studies; however, in the study by Brink et al. (2008), bone density was not affected by isoflavones [73]. However, a higher number of studies is necessary to confirm these results.

Only one study investigated the effect of flavanones, in particular hesperidin on vascular function, providing $320 \mathrm{mg}$ with $767 \mathrm{~mL}$ orange juice/day as acute consumption. Despite the detection of several hesperidin metabolites in plasma (hesperidin-glucuronide, naringenin-7-O-glucuronide, dihydroferulic acid, dihydroferulic acid-glucuronide, hippuric acid, and vanillic acid 4-hydroxyphenylacetic acid) after $5 \mathrm{~h}$, no significant effects were measured. Despite previous studies showing that plasma hesperidin metabolites were correlated with health effects on the endothelium after flavanone acute consumption $[75,76]$, further investigations are necessary to evaluate and support the biological effects of these polyphenols.

\section{Conclusions}

The data reported in this review highlight that, despite the very large number of studies investigating the health effects of polyphenols in humans, only a few have considered their bioavailability in order to partially support the associated bio-efficacy. The bioavailability of polyphenols varies among the different classes and ranks as follows: phenolic acids $>$ isoflavones $>$ flavonols $>$ catechins $>$ flavanones, proanthocyanidins $>$ anthocyanins, confirming data from previous pharmacokinetic studies [20]. Apart from favanols and flavonols, the amounts of polyphenols used in studies were considered to be too low to reach significant plasma concentrations that would provide beneficial effects. However, the amounts were chosen on the basis of the mean consumption in the daily diet of the populations included in the studies. Another point to be considered is that healthy subjects were mainly included in clinical trials. On the one hand, it makes it more difficult to measure significant changes in biomarkers generally associated with pathological conditions; on the other hand, it suggests a potential role of polyphenols provided with the daily diet or supplementation in maintaining the health status. In fact, positive variations of physiological parameters generated by polyphenol intake could help in improving or modulating specific functions and reducing some risk factors for chronic diseases. Cardiovascular function was the main health area investigated. Vasodilator effects were found for phenolic acids (mainly chlorogenic acid and ferulic acid) and flavanols (in particular catechins and proanthocyanidins), which were partially explained by their bioavailability.

As regards anthocyanins, their plasmatic levels were too low to affect the biomarkers considered; however, cyanidin and peonidin were the most available. Future research should focus on confirming and integrating the data discussed in this review, particularly for stilbenes, isoflavones, and flavanones, since few studies have associated their bioavailability with health effects. In addition, the biological effects of phenol metabolites derived from microbiota fermentation should be more extensively studied, since several data suggest their role in mediating the benefits of polyphenols. 
Finally, since polyphenol bioavailability can be affected by food matrix components, specific strategies could be considered in order to increase their in vivo delivery (e.g., fermentation or exploiting the association among foods), or to protect them from degradation (e.g., microencapsulation).

Author Contributions: Writing—original draft preparation, C.D.L.; methodology, F.C.; data curation, C.S. and S.B.; supervision, P.R. All authors have read and agreed to the published version of the manuscript.

Funding: This research received no external funding.

Institutional Review Board Statement: Not applicable.

Informed Consent Statement: Not applicable.

Data Availability Statement: No new data were created or analyzed in this study. Data sharing is not applicable to this article.

Conflicts of Interest: The authors declare no conflict of interest.

\section{References}

1. Tufarelli, V.; Casalino, E.; D'Alessandro, A.G.; Laudadio, V. Dietary Phenolic Compounds: Biochemistry, Metabolism and Significance in Animal and Human Health. Curr. Drug Metab. 2017, 18, 905-913. [CrossRef] [PubMed]

2. Stockley, C.; Teissedre, P.L.; Boban, M.; Di Lorenzo, C.; Restani, P. Bioavailability of wine-derived phenolic compounds in humans: A review. Food Funct. 2012, 3, 995-1007. [CrossRef] [PubMed]

3. Cory, H.; Passarelli, S.; Szeto, J.; Tamez, M.; Mattei, J. The Role of Polyphenols in Human Health and Food Systems: A Mini-Review. Front. Nutr. 2018, 5, 87. [CrossRef] [PubMed]

4. Teng, H.; Chen, L. Polyphenols and bioavailability: An update. Crit. Rev. Food Sci. Nutr. 2019, 59, 2040-2051. [CrossRef]

5. Tresserra-Rimbau, A.; Lamuela-Raventos, R.M.; Moreno, J.J. Polyphenols, food and pharma. Current knowledge and directions for future research. Biochem. Pharmacol. 2018, 156, 186-195. [CrossRef] [PubMed]

6. Ros, E.; Martínez-González, M.A.; Estruch, R.; Salas-Salvadó, J.; Fitó, M.; Martínez, J.A.; Corella, D. Mediterranean diet and cardiovascular health: Teachings of the PREDIMED Study. Adv. Nutr. 2014, 5, 330S-336S. [CrossRef]

7. Del Bo, C.; Bernardi, S.; Marino, M.; Porrini, M.; Tucci, M.; Guglielmetti, S.; Cherubini, A.; Carrieri, B.; Kirkup, B.; Kroon, P.; et al. Systematic Review on Polyphenol Intake and Health Outcomes: Is there Sufficient Evidence to Define a Health-Promoting Polyphenol-Rich Dietary Pattern? Nutrients 2019, 11, 1355. [CrossRef]

8. Pérez-Jiménez, J.; Neveu, V.; Vos, F.; Scalbert, A. Systematic analysis of the content of 502 Polyphenols in 452 foods and beverages: An application of the phenol-explorer database. J. Agric. Food Chem. 2010, 58, 4959-4969. [CrossRef]

9. Pounis, G.; Tabolacci, C.; Costanzo, S.; Cordella, M.; Bonaccio, M.; Rago, L.; D’Arcangelo, D.; Filippo Di Castelnuovo, A.; de Gaetano, G.; Donati, M.B.; et al. Reduction by coffee consumption of prostate cancer risk: Evidence from the Moli-sani cohort and cellular models. Int. J. Cancer 2017, 141, 72-82. [CrossRef]

10. Miranda, A.M.; Steluti, J.; Fisberg, R.M.; Marchioni, D.M. Dietary intake and food contributors of polyphenols in adults and elderly adults of Sao Paulo: A population-based study. Br. J. Nutr. 2016, 115, 1061-1070. [CrossRef]

11. Kent, K.; Charlton, K.E.; Lee, S.; Mond, J.; Russell, J.; Mitchell, P.; Flood, V.M. Dietary flavonoid intake in older adults: How many days of dietary assessment are required and what is the impact of seasonality? Nutr. J. 2018, 17, 7. [CrossRef] [PubMed]

12. Tena, N.; Martín, J.; Asuero, A.G. State of the art of anthocyanins: Antioxidant activity, sources, bioavailability, and therapeutic effect in human health. Antioxidants 2020, 9, 451. [CrossRef]

13. Xie, L.; Vance, T.; Kim, B.; Lee, S.G.; Caceres, C.; Wang, Y.; Hubert, P.A.; Lee, J.Y.; Chun, O.K.; Bolling, B.W. Aronia berry polyphenol consumption reduces plasma total and low-density lipoprotein cholesterol in former smokers without lowering biomarkers of inflammation and oxidative stress: A randomized controlled trial. Nutr. Res. 2017, 37, 67-77. [CrossRef] [PubMed]

14. Broncel, M.; Koziróg, M.; Duchnowicz, P.; Koter-Michalak, M.; Sikora, J.; Chojnowska-Jezierska, J. Aronia melanocarpa extract reduces blood pressure, serum endothelin, lipid, and oxidative stress marker levels in patients with metabolic syndrome. Med. Sci. Monit. 2010, 16, CR28-CR34. [PubMed]

15. Skoczyńska, A.; Jedrychowska, I.; Poreba, R.; Affelska-Jercha, A.; Turczyn, B.; Wojakowska, A.; Andrzejak, R. Influence of chokeberry juice on arterial blood pressure and lipid parameters in men with mild hypercholesterolemia. Pharmacol. Rep. 2007, 59, 177-182.

16. Jin, Y.; Alimbetov, D.; George, T.; Gordon, M.H.; Lovegrove, J.A. A randomised trial to investigate the effects of acute consumption of a blackcurrant juice drink on markers of vascular reactivity and bioavailability of anthocyanins in human subjects. Eur. J. Clin. Nutr. 2011, 65, 849-856. [CrossRef] [PubMed]

17. Cao, G.; Prior, R.L. Anthocyanins are detected in human plasma after oral administration of an elderberry extract. Clin. Chem. 1999, 45, 574-576. [CrossRef] 
18. Murkovic, M.; Toplak, H.; Adam, U.; Pfannhauser, W. Analysis of anthocyanins in plasma for determination of their bioavailability. J. Food Compos. Anal. 2000, 13, 291-296. [CrossRef]

19. Sangiovanni, E.; Di Lorenzo, C.; Colombo, E.; Colombo, F.; Fumagalli, M.; Frigerio, G.; Restani, P.; Dell'Agli, M. The effect of in vitro gastrointestinal digestion on the anti-inflammatory activity of Vitis vinifera L. leaves. Food Funct. 2015, 6, $2453-2463$. [CrossRef]

20. Manach, C.; Williamson, G.; Morand, C.; Scalbert, A.; Rémésy, C. Bioavailability and bioefficacy of polyphenols in humans. I. Review of 97 bioavailability studies. Am. J. Clin. Nutr. 2005, 81, 230-242. [CrossRef]

21. Hollands, W.; Brett, G.M.; Radreau, P.; Saha, S.; Teucher, B.; Bennett, R.N.; Kroon, P.A. Processing blackcurrants dramatically reduces the content and does not enhance the urinary yield of anthocyanins in human subjects. Food Chem. 2008, 108, 869-878. [CrossRef] [PubMed]

22. Wedick, N.M.; Pan, A.; Cassidy, A.; Rimm, E.B.; Sampson, L.; Rosner, B.; Willett, W.; Hu, F.B.; Sun, Q.; Van Dam, R.M. Dietary flavonoid intakes and risk of type 2 diabetes in US men and women. Am. J. Clin. Nutr. 2012, 95, 925-933. [CrossRef] [PubMed]

23. Cassidy, A.; Bertoia, M.; Chiuve, S.; Flint, A.; Forman, J.; Rimm, E.B. Habitual intake of anthocyanins and flavanones and risk of cardiovascular disease in men. Am. J. Clin. Nutr. 2016, 104, 587-594. [CrossRef]

24. Milbury, P.E.; Vita, J.A.; Blumberg, J.B. Anthocyanins are bioavailable in humans following an acute dose of cranberry juice. J. Nutr. 2010, 140, 1099-1104. [CrossRef] [PubMed]

25. Duthie, S.J.; Jenkinson, A.M.E.; Crozier, A.; Mullen, W.; Pirie, L.; Kyle, J.; Yap, L.S.; Christen, P.; Duthie, G.G. The effects of cranberry juice consumption on antioxidant status and biomarkers relating to heart disease and cancer in healthy human volunteers. Eur. J. Nutr. 2006, 45, 113-122. [CrossRef] [PubMed]

26. Giordano, L.; Coletta, W.; Tamburrelli, C.; D’Imperio, M.; Crescente, M.; Silvestri, C.; Rapisarda, P.; Reforgiato Recupero, G.; De Curtis, A.; Iacoviello, L.; et al. Four-week ingestion of blood orange juice results in measurable anthocyanin urinary levels but does not affect cellular markers related to cardiovascular risk: A randomized cross-over study in healthy volunteers. Eur. J. Nutr. 2012, 51, 541-548. [CrossRef]

27. Riso, P.; Visioli, F.; Gardana, C.; Grande, S.; Brusamolino, A.; Galvano, F.; Galvano, G.; Porrini, M. Effects of blood orange juice intake on antioxidant bioavailability and on different markers related to oxidative stress. J. Agric. Food Chem. 2005, 53, 941-947. [CrossRef]

28. Vogiatzoglou, A.; Mulligan, A.A.; Luben, R.N.; Lentjes, M.A.H.; Heiss, C.; Kelm, M.; Merx, M.W.; Spencer, J.P.E.; Schroeter, H.; Kuhnle, G.G.C. Assessment of the dietary intake of total flavan-3-ols, monomeric flavan-3-ols, proanthocyanidins and theaflavins in the European Union. Br. J. Nutr. 2014, 111, 1463-1473. [CrossRef] [PubMed]

29. Dower, J.I.; Geleijnse, J.M.; Kroon, P.A.; Philo, M.; Mensink, M.; Kromhout, D.; Hollman, P.C.H. Does epicatechin contribute to the acute vascular function effects of dark chocolate? A randomized, crossover study. Mol. Nutr. Food Res. 2016, 60, 2379-2386. [CrossRef]

30. EFSA Panel on Dietetic Products, Nutrition and Allergies (NDA). Scientific Opinion on the modification of the authorisation of a health claim related to cocoa flavanols and maintenance of normal endothelium-dependent vasodilation pursuant to Article 13(5) of Regulation (EC) No 1924/ 2006 following a request in accordan. EFSA J. 2014, 12, 3654. [CrossRef]

31. Engler, M.B.; Engler, M.M.; Chen, C.Y.; Malloy, M.J.; Browne, A.; Chiu, E.Y.; Kwak, H.-K.; Milbury, P.; Paul, S.M.; Blumberg, J.; et al. Flavonoid-rich dark chocolate improves endothelial function and increases plasma epicatechin concentrations in healthy adults. J. Am. Coll. Nutr. 2004, 23, 197-204. [CrossRef]

32. Taubert, D.; Roesen, R.; Lehmann, C.; Jung, N.; Schömig, E. Effects of low habitual cocoa intake on blood pressure and bioactive nitric oxide: A randomized controlled trial. JAMA 2007, 298, 49-60. [CrossRef] [PubMed]

33. Ostertag, L.M.; Kroon, P.A.; Wood, S.; Horgan, G.W.; Cienfuegos-Jovellanos, E.; Saha, S.; Duthie, G.G.; De Roos, B. Flavan3-ol-enriched dark chocolate and white chocolate improve acute measures of platelet function in a gender-specific way-a randomized-controlled human intervention trial. Mol. Nutr. Food Res. 2013, 57, 191-202. [CrossRef] [PubMed]

34. Mena, P.; Bresciani, L.; Brindani, N.; Ludwig, I.A.; Pereira-Caro, G.; Angelino, D.; Llorach, R.; Calani, L.; Brighenti, F.; Clifford, M.N.; et al. Phenyl- $\gamma$-valerolactones and phenylvaleric acids, the main colonic metabolites of flavan-3-ols: Synthesis, analysis, bioavailability, and bioactivity. Nat. Prod. Rep. 2019, 36, 714-752. [CrossRef] [PubMed]

35. Montagnana, M.; Danese, E.; Angelino, D.; Mena, P.; Rosi, A.; Benati, M.; Gelati, M.; Salvagno, G.L.; Favaloro, E.J.; Del Rio, D.; et al. Dark chocolate modulates platelet function with a mechanism mediated by flavan-3-ol metabolites. Medicine 2018, 97, e13432. [CrossRef]

36. Aherne, S.A.; O'Brien, N.M. Dietary flavonols: Chemistry, food content, and metabolism chemistry and structure of the flavonoids. Nutrition 2002, 18, 75-81. [CrossRef]

37. Bondonno, N.P.; Bondonno, C.P.; Ward, N.C.; Woodman, R.J.; Hodgson, J.M.; Croft, K.D. Enzymatically modified isoquercitrin improves endothelial function in volunteers at risk of cardiovascular disease. Br. J. Nutr. 2020, 123, 182-189. [CrossRef]

38. Suomela, J.P.; Ahotupa, M.; Yang, B.; Vasankari, T.; Kallio, H. Absorption of flavonols derived from sea buckthorn (Hippophä rhamnoides L.) and their effect on emerging risk factors for cardiovascular disease in humans. J. Agric. Food Chem. 2006, 54, 7364-7369. [CrossRef] [PubMed]

39. Guo, Y.; Mah, E.; Davis, C.G.; Jalili, T.; Ferruzzi, M.G.; Chun, O.K.; Bruno, R.S. Dietary fat increases quercetin bioavailability in overweight adults. Mol. Nutr. Food Res. 2013, 57, 896-905. [CrossRef] 
40. Hubbard, G.P.; Wolffram, S.; de Vos, R.; Bovy, A.; Gibbins, J.M.; Lovegrove, J.A. Ingestion of onion soup high in quercetin inhibits platelet aggregation and essential components of the collagen-stimulated platelet activation pathway in man: A pilot study. Br. J. Nutr. 2006, 96, 482-488. [CrossRef]

41. Beatty, E.R.; O’Reilly, J.D.; England, T.G.; McAnlis, G.T.; Young, I.S.; Halliwell, B.; Geissler, C.A.; Sanders, T.A.B.; Wiseman, H. Effect of dietary quercetin on oxidative DNA damage in healthy human subjects. Br. J. Nutr. 2000, 84, 919-925. [CrossRef]

42. O'Reilly, J.D.; Mallet, A.I.; McAnlis, G.T.; Young, I.S.; Halliwell, B.; Sanders, T.A.B.; Wiseman, H. Consumption of flavonoids in onions and black tea: Lack of effect on F2-isoprostanes and autoantibodies to oxidized LDL in healthy humans. Am. J. Clin. Nutr. 2001, 73, 1040-1044. [CrossRef] [PubMed]

43. Larmo, P.S.; Yang, B.; Hurme, S.A.M.; Alin, J.A.; Kallio, H.P.; Salminen, E.K.; Tahvonen, R.L. Effect of a low dose of sea buckthorn berries on circulating concentrations of cholesterol, triacylglycerols, and flavonols in healthy adults. Eur. J. Nutr. 2009, 48, 277-282. [CrossRef]

44. Arts, I.C.W.; Hollman, P.C.H. Polyphenols and disease risk in epidemiologic studies. Am. J. Clin. Nutr. 2005, 81, 317S-325S. [CrossRef]

45. State Pharmacopoeia Commission of the PRC. Pharmacopoeia of the People's Republic of China (The First Part); People's Medical Publishing House: Beijing, China, 2000; Volume I, ISBN 9787117069823. (In English)

46. Wang, J.; Zhang, M.; Xu, Z.; Zhang, T.; Cheng, Y. Clinical observation on effects of sea buckthorn total flavones on ischemic heart diseases. Shanxi Med. Res. 1985, 2, 60-67.

47. Bondonno, N.P.; Bondonno, C.P.; Rich, L.; Mas, E.; Shinde, S.; Ward, N.C.; Hodgson, J.M.; Croft, K.D. Acute effects of quercetin-3-O-glucoside on endothelial function and blood pressure: A randomized dose-response study. Am. J. Clin. Nutr. 2016, 104, 97-103. [CrossRef]

48. Hubbard, G.P.; Wolffram, S.; Lovegrove, J.A.; Gibbins, J.M. Ingestion of quercetin inhibits platelet aggregation and essential components of the collagen-stimulated platelet activation pathway in humans. J. Thromb. Haemost. 2004, 2, 2138-2145. [CrossRef] [PubMed]

49. Loke, W.M.; Hodgson, J.M.; Proudfoot, J.M.; McKinley, A.J.; Puddey, I.B.; Croft, K.D. Pure dietary flavonoids quercetin and (-)-epicatechin augment nitric oxide products and reduce endothelin-1 acutely in healthy men. Am. J. Clin. Nutr. 2008, 88, 1018-1025. [CrossRef]

50. Perez, A.; Gonzalez-Manzano, S.; Jimenez, R.; Perez-Abud, R.; Haro, J.M.; Osuna, A.; Santos-Buelga, C.; Duarte, J.; Perez-Vizcaino, F. The flavonoid quercetin induces acute vasodilator effects in healthy volunteers: Correlation with beta-glucuronidase activity. Pharmacol. Res. 2014, 89, 11-18. [CrossRef]

51. Bento-Silva, A.; Koistinen, V.M.; Mena, P.; Bronze, M.R.; Hanhineva, K.; Sahlstrøm, S.; Kitryte, V.; Moco, S.; Aura, A.M. Factors affecting intake, metabolism and health benefits of phenolic acids: Do we understand individual variability? Eur. J. Nutr. 2020, 59, 1275-1293. [CrossRef] [PubMed]

52. Herrmann, K.; Nagel, C.W. Occurrence and content of hydroxycinnamic and hydroxybenzoic acid compounds in foods. Crit. Rev. Food Sci. Nutr. 1989, 28, 315-347. [CrossRef] [PubMed]

53. Ludwig, I.A.; Mena, P.; Calani, L.; Cid, C.; Del Rio, D.; Lean, M.E.J.; Crozier, A. Variations in caffeine and chlorogenic acid contents of coffees: What are we drinking? Food Funct. 2014, 5, 1718-1726. [CrossRef] [PubMed]

54. El-Seedi, H.R.; El-Said, A.M.A.; Khalifa, S.A.M.; Göransson, U.; Bohlin, L.; Borg-Karlson, A.K.; Verpoorte, R. Biosynthesis, natural sources, dietary intake, pharmacokinetic properties, and biological activities of hydroxycinnamic acids. J. Agric. Food Chem. 2012, 60, 10877-10895. [CrossRef] [PubMed]

55. Mills, C.E.; Flury, A.; Marmet, C.; Poquet, L.; Rimoldi, S.F.; Sartori, C.; Rexhaj, E.; Brenner, R.; Allemann, Y.; Zimmermann, D.; et al. Mediation of coffee-induced improvements in human vascular function by chlorogenic acids and its metabolites: Two randomized, controlled, crossover intervention trials. Clin. Nutr. 2017, 36, 1520-1529. [CrossRef]

56. Mubarak, A.; Bondonno, C.P.; Liu, A.H.; Considine, M.J.; Rich, L.; Mas, E.; Croft, K.D.; Hodgson, J.M. Acute effects of chlorogenic acid on nitric oxide status, endothelial function, and blood pressure in healthy volunteers: A randomized trial. J. Agric. Food Chem. 2012, 60, 9130-9136. [CrossRef] [PubMed]

57. Kim, B.; Nam, Y.; Kim, J.; Choi, H.; Won, C. Coffee consumption and stroke risk: A meta-analysis of epidemiologic studies. Korean J. Fam. Med. 2012, 33, 356-365. [CrossRef]

58. Lafay, S.; Morand, C.; Manach, C.; Besson, C.; Scalbert, A. Absorption and metabolism of caffeic acid and chlorogenic acid in the small intestine of rats. Br. J. Nutr. 2006, 96, 39-46. [CrossRef]

59. Agudelo-Ochoa, G.M.; Pulgarín-Zapata, I.C.; Velásquez-Rodriguez, C.M.; Duque-Ramírez, M.; Naranjo-Cano, M.; Quintero-Ortiz, M.M.; Lara-Guzmán, O.J.; Muñoz-Durango, K. Coffee consumption increases the antioxidant capacity of plasma and has no effect on the lipid profile or vascular function in healthy adults in a randomized controlled trial. J. Nutr. 2016, 146, 524-531. [CrossRef]

60. Boon, E.A.J.; Croft, K.D.; Shinde, S.; Hodgson, J.M.; Ward, N.C. The acute effect of coffee on endothelial function and glucose metabolism following a glucose load in healthy human volunteers. Food Funct. 2017, 8, 3366-3373. [CrossRef]

61. Rodriguez-Mateos, A.; Rendeiro, C.; Bergillos-Meca, T.; Tabatabaee, S.; George, T.W.; Heiss, C.; Spencer, J.P.E. Intake and time dependence of blueberry flavonoid-induced improvements in vascular function: A randomized, controlled, double-blind, crossover intervention study with mechanistic insights into biological activity. Am. J. Clin. Nutr. 2013, 98, 1179-1191. [CrossRef]

62. Vitaglione, P.; Mennella, I.; Ferracane, R.; Rivellese, A.A.; Giacco, R.; Ercolini, D.; Gibbons, S.M.; La Storia, A.; Gilbert, J.A.; Jonnalagadda, S.; et al. Whole-grain wheat consumption reduces inflammation in a randomized controlled trial on overweight and obese subjects with unhealthy dietary and lifestyle behaviors: Role of polyphenols bound to cereal dietary fiber. Am. J. Clin. Nutr. 2015, 101, 251-261. [CrossRef] [PubMed] 
63. Ward, N.C.; Hodgson, J.M.; Woodman, R.J.; Zimmermann, D.; Poquet, L.; Leveques, A.; Actis-Goretta, L.; Puddey, I.B.; Croft, K.D. Acute effects of chlorogenic acids on endothelial function and blood pressure in healthy men and women. Food Funct. 2016, 7, 2197-2203. [CrossRef] [PubMed]

64. Kempf, K.; Herder, C.; Erlund, I.; Kolb, H.; Martin, S.; Carstensen, M.; Koenig, W.; Sundvall, J.; Bidel, S.; Kuha, S.; et al. Effects of coffee consumption on subclinical inflammation and other risk factors for type 2 diabetes: A clinical trial. Am. J. Clin. Nutr. 2010, 91, 950-957. [CrossRef]

65. Lara-Guzmán, O.J.; Álvarez-Quintero, R.; Osorio, E.; Naranjo-Cano, M.; Muñoz-Durango, K. GC/MS method to quantify bioavailable phenolic compounds and antioxidant capacity determination of plasma after acute coffee consumption in human volunteers. Food Res. Int. 2016, 89, 219-226. [CrossRef]

66. Rinninella, E.; Raoul, P.; Cintoni, M.; Franceschi, F.; Miggiano, G.A.D.; Gasbarrini, A.; Mele, M.C. What is the healthy gut microbiota composition? A changing ecosystem across age, environment, diet, and diseases. Microorganisms 2019, 7, 14. [CrossRef] [PubMed]

67. Renouf, M.; Guy, P.A.; Marmet, C.; Fraering, A.L.; Longet, K.; Moulin, J.; Enslen, M.; Barron, D.; Dionisi, F.; Cavin, C.; et al. Measurement of caffeic and ferulic acid equivalents in plasma after coffee consumption: Small intestine and colon are key sites for coffee metabolism. Mol. Nutr. Food Res. 2010, 54, 760-766. [CrossRef]

68. Wightman, E.L.; Haskell-Ramsay, C.F.; Reay, J.L.; Williamson, G.; Dew, T.; Zhang, W.; Kennedy, D.O. The effects of chronic trans-resveratrol supplementation on aspects of cognitive function, mood, sleep, health and cerebral blood flow in healthy, young humans. Br. J. Nutr. 2015, 114, 1427-1437. [CrossRef] [PubMed]

69. Kennedy, D.O.; Wightman, E.L.; Reay, J.L.; Lietz, G.; Okello, E.J.; Wilde, A.; Haskell, C.F. Effects of resveratrol on cerebral blood flow variables and cognitive performance in humans: A double-blind, placebo-controlled, crossover investigation. Am. J. Clin. Nutr. 2010, 91, 1590-1597. [CrossRef] [PubMed]

70. Pastor, R.F.; Restani, P.; Di Lorenzo, C.; Orgiu, F.; Teissedre, P.L.; Stockley, C.; Ruf, J.C.; Quini, C.I.; Garcìa Tejedor, N.; Gargantini, R.; et al. Resveratrol, human health and winemaking perspectives. Crit. Rev. Food Sci. Nutr. 2019, 59, 1237-1255. [CrossRef] [PubMed]

71. Hanwell, H.E.C.; Kay, C.D.; Lampe, J.W.; Holub, B.J.; Duncan, A.M. Acute fish oil and soy isoflavone supplementation increase postprandial serum (n-3) polyunsaturated fatty acids and isoflavones but do not affect triacylglycerols or biomarkers of oxidative stress in overweight and obese hypertriglyceridemic men. J. Nutr. 2009, 139, 1128-1134. [CrossRef] [PubMed]

72. Lambert, M.N.T.; Thybo, C.B.; Lykkeboe, S.; Rasmussen, L.M.; Frette, X.; Christensen, L.P.; Jeppesen, P.B. Combined bioavailable isoflavones and probiotics improve bone status and estrogen metabolism in postmenopausal osteopenic women: A randomized controlled trial. Am. J. Clin. Nutr. 2017, 106, 909-920. [CrossRef] [PubMed]

73. Brink, E.; Coxam, V.; Robins, S.; Wahala, K.; Cassidy, A.; Branca, F. Long-term consumption of isoflavone-enriched foods does not affect bone mineral density, bone metabolism, or hormonal status in early postmenopausal women: A randomized, double-blind, placebo controlled study. Am. J. Clin. Nutr. 2008, 87, 761-770. [CrossRef]

74. Schar, M.Y.; Curtis, P.J.; Hazim, S.; Ostertag, L.M.; Kay, C.D.; Potter, J.F.; Cassidy, A. Orange juice-derived flavanone and phenolic metabolites do not acutely affect cardiovascular risk biomarkers: A randomized, placebo-controlled, crossover trial in men at moderate risk of cardiovascular disease1-5. Am. J. Clin. Nutr. 2015, 101, 931-938. [CrossRef] [PubMed]

75. Morand, C.; Dubray, C.; Milenkovic, D.; Lioger, D.; Martin, J.F.; Scalbert, A.; Mazur, A. Hesperidin contributes to the vascular protective effects of orange juice: A randomized crossover study in healthy volunteers. Am. J. Clin. Nutr. 2011, 93, 73-80. [CrossRef] [PubMed]

76. Rendeiro, C.; Dong, H.; Saunders, C.; Harkness, L.; Blaze, M.; Hou, Y.; Belanger, R.L.; Corona, G.; Lovegrove, J.A.; Spencer, J.P.E. Flavanone-rich citrus beverages counteract the transient decline in postprandial endothelial function in humans: A randomised, controlled, double-masked, cross-over intervention study. Br. J. Nutr. 2016, 116, 1999-2010. [CrossRef] [PubMed] 